\title{
Late Quaternary Cuiabá megafan, Brazilian Pantanal: Channel patterns and paleoenvironmental changes
}

\author{
Fabiano do Nascimento Pupim ${ }^{\text {a, b, }}$, , Mario Luis Assine ${ }^{\text {b }}$, André Oliveira Sawakuchi ${ }^{\text {a }}$ \\ ${ }^{a}$ Universidade de São Paulo - USP, Instituto de Geociências, Rua do Lago, 562, São Paulo, SP 05508-080, Brazil \\ ${ }^{\mathrm{b}}$ Universidade Estadual Paulista - Unesp, Instituto de Geociências e Ciências Exatas, Avenida 24A, 1515, Rio Claro, SP 13506-900, Brazil
}

\section{A R T I C L E I N F O}

\section{Article history:}

Received 11 July 2016

Received in revised form

18 December 2016

Accepted 13 January 2017

Available online 3 March 2017

\section{Keywords:}

Fluvial megafan

Distributary system

Paleohydrology

Climate changes

Pantanal wetlands

\begin{abstract}
A B S T R A C T
The Brazilian Pantanal wetlands comprise some of the largest Quaternary megafans in South America. The origin of these megafans has been linked to climate changes during the Late Quaternary. This study focuses on the Cuiabá megafan, the second largest megafan of the Pantanal, which has not been studied from the perspective of its basic geomorphology, river channel patterns and sediment deposition ages. Analysis of the channel and floodplain morphology as well as optically stimulated luminescence dating enable us to establish the succession of events that built up the Cuiabá megafan since the last glacial period. Abandoned lobes indicate that a phase of fan aggradation occurred between 48 and $19 \mathrm{ka}$, with a network of distributary paleochannels suggesting that there was relatively low precipitation and reduced vegetation cover. Subsequently, abrupt changes in discharge and sediment supply triggered the channel incision of the upper fan valley, indicating a degradational phase after the Last Glacial Maximum $(<19$ ka). A new phase of fan aggradation began at the Early Holocene, when meandering and anabranching channels were constrained into the incised valley on the upper fan. In the distal part of the fan, the development of modern depositional lobes has been driven by numerous single-sinuous channels that shift laterally due to successive avulsions. Regional tectonic features suggest that modern Cuiabá lobes are in a subsiding area that provides accommodation space for sediment accumulation and prolonged flooding events. Changes in the channel patterns observed in the Cuiabá megafan are related to changes in the South American monsoon strength, which driven precipitation variation during the Late Quaternary. Periods of monsoon intensification and relatively high precipitation lead to channel incision, while periods of fan aggradation correlate to times of fewer oscillations. Our findings highlighted the diversity of fluvial styles in the Pantanal and its importance as a climate changes archives in the South American lowlands.
\end{abstract}

() 2017 Elsevier Ltd and INQUA. All rights reserved.

\section{Introduction}

Quaternary fluvial megafans are common depositional systems in most continental sedimentary basins around the world (DeCelles and Cavazza, 1999; Leier et al., 2005; Weissmann et al., 2010), but they are remarkably well developed in South American basins (e.g., Iriondo, 1993; Horton and Decelles, 2001; Wilkinson et al., 2006; Latrubesse et al., 2012; Rossetti et al., 2014). The Brazilian Pantanal wetlands, like the modern depositional tract of the Chaco Plain, comprises some of the largest Quaternary megafans in South

\footnotetext{
* Corresponding author. Universidade de São Paulo - USP, Instituto de Geociências, Rua do Lago, 562, São Paulo, SP 05508-080, Brazil.

E-mail addresses: fabianopupim@usp.br, fabianopupim@gmail.com (F.N. Pupim).
}

America (Assine et al., 2015a; Latrubesse, 2015).

The Pantanal wetlands is largely constrained by subsidence in an interior Quaternary sedimentary basin in central-west Brazil at the Upper Paraguay River Basin (Clapperton, 1993; Assine and Soares, 2004). Sediment deposition takes place on a large alluvial setting characterized by the interaction of fluvial megafans and interfan river plains, as well as by the Paraguay trunk-river that collects water from the entire basin (Fig. 1). These distinct alluvial systems are part of a large depositional system tract and result from the geomorphological heterogeneity of the basin.

A classification of Pantanal fluvial megafan systems was recently proposed by Assine et al. (2015a), in which distinct groups of systems are related to sediment source-areas with specific geomorphological characteristics (Fig. 1). Fluvial fans formed by rivers derived from tableland-catchment source-areas developed over 


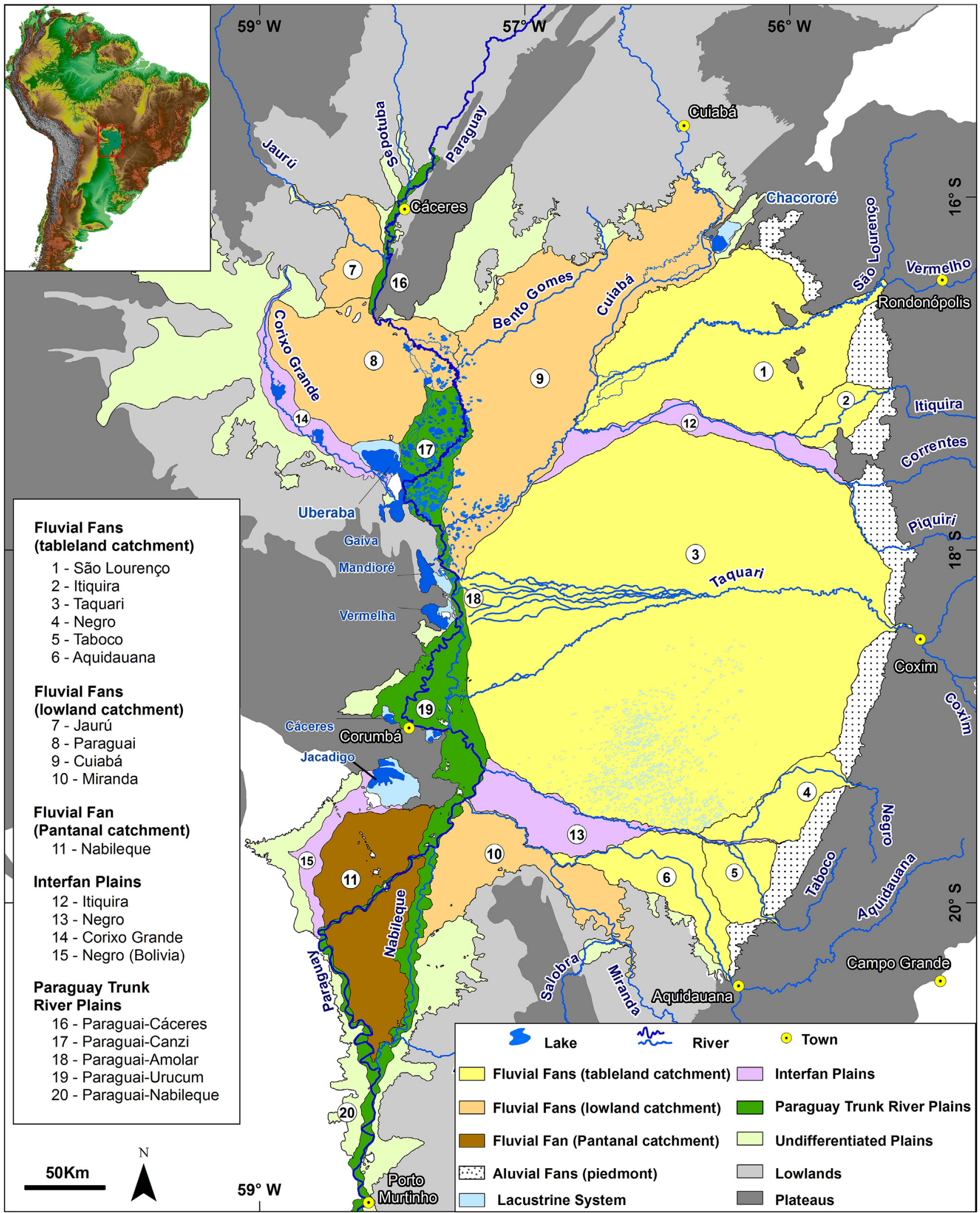

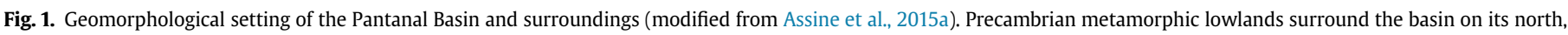

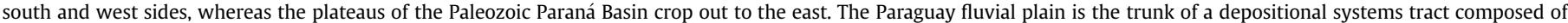
several river-dominated fans, fluvial plains and permanent lakes. The Cuiabá fluvial megafan (9) is the target area of this study. 
siliciclastic rocks are the most studied to date, including megafans with high sediment yields, which can reach up to 22.5 million ton/ year, such as the Taquari and São Lourenço megafans (Braun, 1977; Tricart, 1982; Assine and Soares, 2004; Buehler et al., 2011; Makaske et al., 2012; Zani et al., 2012; Assine et al., 2014). These systems are characterized by an axial entrenched meander belt in the upper fan, but the loss of confinement downstream results in multiple narrow and shallow distributary channels, which progressively decrease in discharge volume and form modern lowerfan lobes (Assine, 2005; Assine et al., 2014).

By contrast, there is still a lack of knowledge regarding the dynamics and development of fluvial megafans sourced from catchments in the deeply dissected Precambrian lowland regions formed by igneous and metamorphic rocks (Pupim et al., 2015). The sediment yield of these systems is considerably smaller than that of the fans sourced from sedimentary tablelands, which carry less than 1.1 million ton/year of suspended load into the Pantanal plain (Assine et al., 2015a). The Paraguay and Miranda fluvial fans are examples of this type of system (Assine and Silva, 2009; Merino et al., 2013). The Cuiabá fluvial fan, the largest megafan of this group, has not been studied from the perspective of its basic geomorphological mapping, river channel patterns and sediment deposition ages.

The origin and development of the Pantanal megafans have been linked to environmental changes during the Late Quaternary. Braun (1977) was the first to interpret that the landscape of the Taquari megafan is mostly composed by relict depositional landforms that originated under semiarid conditions during the Late Pleistocene. Klammer (1982) and Tricart (1982) interpreted that most of the landforms exposed on the Taquari fan surface, including the deflation pans and lunettes, were formed by aeolian processes. These early insights led Ab'Sáber (1988) and Clapperton (1993) to argue that the climate was arid to semiarid during the Last Glacial Maximum (LGM). However, most of these interpretations are not completely satisfactory due the absence of absolute chronological control and limited surface information and ground truth.

Despite the small amount of geochronological data available for Pantanal, the OSL ages from the sediments of the São Lourenço megafan provide good evidence that Quaternary climate change may have influenced shifts in channel patterns, from distributary systems dominated by braided channels in the Late Pleistocene to meandering rivers and low sinuosity rivers prevailing during the Holocene (Assine et al., 2014). However, more detailed data on the sedimentary archives of Pantanal are available from the lakes on the western side of the Paraguay River floodplain that recorded important changes in climate, vegetation, and surface processes since the Late Pleistocene (Whitney et al., 2011; McGlue et al., 2012).

This paper focuses on the Cuiabá megafan in attempt to (i) characterize its geomorphic features, channel patterns and fluvial processes; (ii) reconstruct the Quaternary landforms that have led to its present morphological configuration; and (iii) constrain the chronology of sediment accumulation and establish the succession of depositional and erosional events that possibly resulted from the interactions between tectonic and climate forces. Few studies address the response of South American fluvial megafans to Quaternary climate and tectonic changes (e.g., Iriondo, 1993; Latrubesse et al., 2012; Zani et al., 2012; Assine et al., 2014) due to the lack of chronological control for depositional units and erosion surfaces. The geochronological data presented here allow for an investigation of how Late Quaternary climate changes control sedimentary processes in tropical lowlands, adding new dating information to the scarce database for the sediments of the Pantanal wetland. The understanding of the geomorphological zonation and evolution of the Cuiabá fan provides novel information and insights into the dynamics of fluvial fans sourced by rivers from catchments with low-relief and with low sediment yield.

\section{Physical settings}

The Pantanal is a tectonically active sedimentary basin with a surface area of approximately $150,000 \mathrm{~km}^{2}$ and relief ranging from 80 to $200 \mathrm{~m}$. The sediment thickness reaches $500 \mathrm{~m}$ (Assine and Soares, 2004), and the origin of the basin has been associated with the Andean foreland system (Horton and DeCelles, 1997; Ussami et al., 1999). The faults have dip displacements from tens to hundreds of meters, delineating a basin geometry that is characterized by horst and grabens that define blocks with differential subsidence and flooding patterns (Assine et al., 2015b). Faults are evident in the basin morphology, conditioning the occurrence of Precambrian terranes at the western edge of the basin and the modern alluvial drainage within the basin (Assine and Soares, 2004; Zani et al., 2012). Further evidence for active tectonism can be found in the Brazilian earthquake catalog, in which seismic events usually do not exceed a magnitude $m_{b}$ of 4.0 , although there are occasional events with an $\mathrm{m}_{\mathrm{b}}$ of approximately 5.0 (Assumpção et al., 2014).

The climate of the Pantanal is tropical with a marked dry season from May to October. The mean annual precipitation ranges from $1500 \mathrm{~mm}$ east and north on the uplands to $1000 \mathrm{~mm}$ within the basin (Hamilton, 2002). The annual precipitation distribution is controlled by the South American summer monsoon (SASM), leading to heavy convective rainfall in austral summer and markedly dry conditions during winter (Zhou and Lau, 1998). A very deep continental low forms over the Chaco region during austral summer and forces the northeasterly winds over the Amazon to turn southward, transporting large amounts of moisture that feeds summertime convective storms over the subtropical plains as far south as $35^{\circ} \mathrm{S}$ (Garreaud et al., 2009). The mean annual temperature is approximately $25{ }^{\circ} \mathrm{C}$, and evaporation exceeds precipitation during most of the year (Por, 1995). The region experiences extreme temperature highs of up to $40-44{ }^{\circ} \mathrm{C}$ during summer, while advances of cold polar fronts can reduce the temperature by $5-10{ }^{\circ} \mathrm{C}$ during winter (Alho, 2005).

The monsoonal peak river discharge during austral summer and the existence of hydraulic bottlenecks along the Paraguay River course (Assine et al., 2015c) cause widespread inundations, making the Pantanal one of the largest wetlands in the world (Fraser and Keddy, 2005; Junk et al., 2006). The Cuiabá River is a typical seasonal river with two contrasting hydrological periods during the year, as seen in the hydrograph records of six fluvial gauge stations (Fig. 2A). The river annual discharge at the Cuiabá station is $1,76 \times 10^{6} \mathrm{~m}^{3}, 72 \%$ of which occurs from December to April (wet season). The monthly average discharge decreases from $590 \mathrm{~m}^{3} / \mathrm{s}$ in the wet season to $162 \mathrm{~m}^{3} / \mathrm{s}$ in the dry season.

The spatial distribution of major vegetation types is controlled by the local topography, seasonal flooding and soil type (Prance and Schaller, 1982). There are two main vegetation domains: fluvial flood ( $1-5 \mathrm{~m}$ ) on clayey eutrophic soils with gallery forests, pioneer forests and scrubs, seasonal swamps, grasslands and oxbow lakes; and pluvial flood $(10-80 \mathrm{~cm})$ mainly on dystrophic sandy soils $(72 \%$ of the total area) with cerrado forest (tropical savanna), grasslands and woodlands (Adámoli and Pott, 1999).

\section{Material and methods}

Our investigative approach was based on remote sensing methods coupled to field surveys to characterize the geomorphic features and historic hydrological data as well as to optically stimulated luminescence (OSL) dating of sediments. Downstream trend analysis considered parameters such as water flow and 

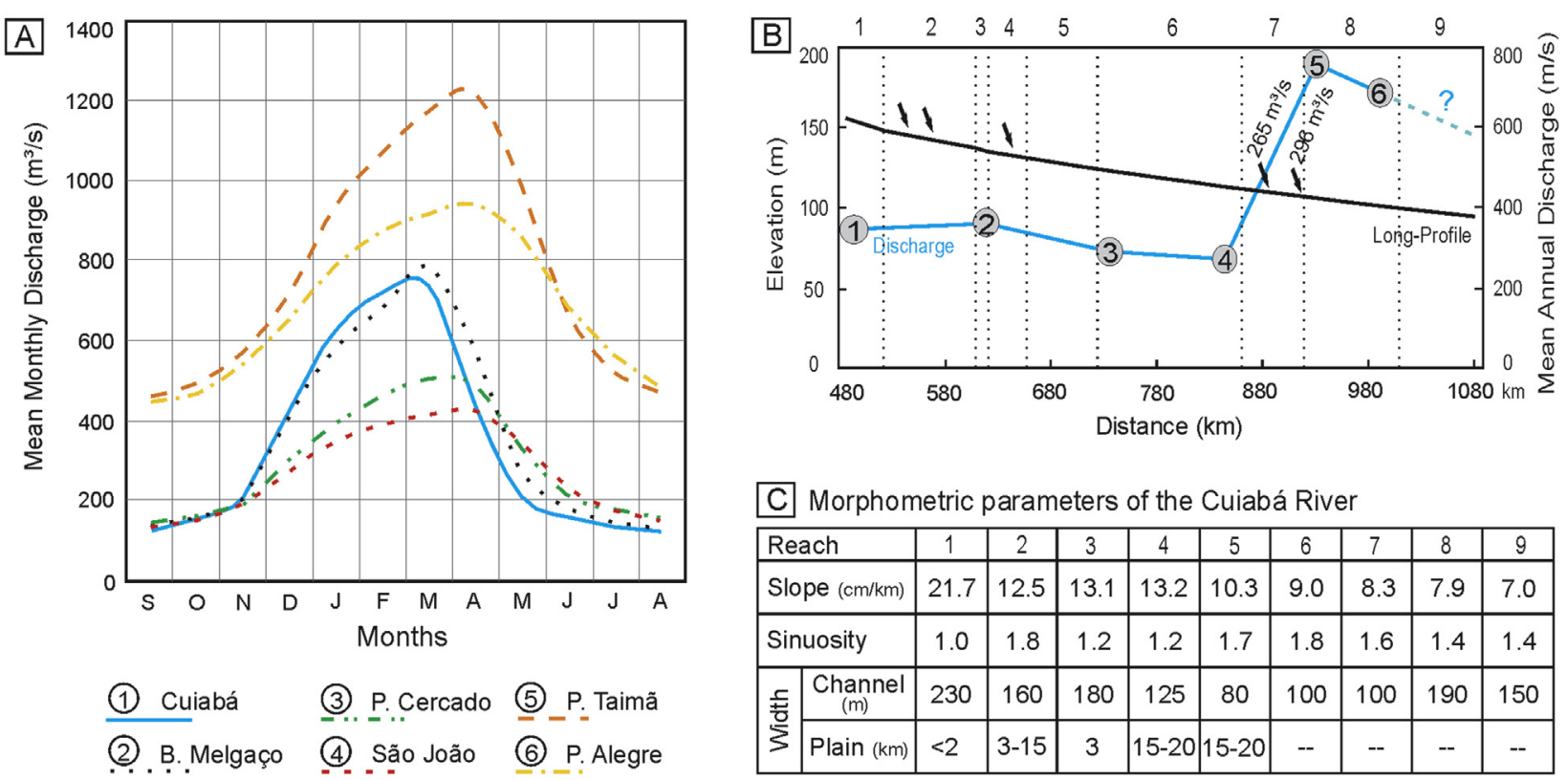

C Morphometric parameters of the Cuiabá River

\begin{tabular}{|c|c|c|c|c|c|c|c|c|c|c|}
\hline \multicolumn{2}{|c|}{ Reach } & 1 & 2 & 3 & 4 & 5 & 6 & 7 & 8 & 9 \\
\hline \multicolumn{2}{|c|}{ Slope $(\mathrm{cm} / \mathrm{km})$} & 21.7 & 12.5 & 13.1 & 13.2 & 10.3 & 9.0 & 8.3 & 7.9 & 7.0 \\
\hline \multicolumn{2}{|c|}{ Sinuosity } & 1.0 & 1.8 & 1.2 & 1.2 & 1.7 & 1.8 & 1.6 & 1.4 & 1.4 \\
\hline \multirow{2}{*}{ 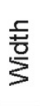 } & $\underset{(m)}{C}$ & 230 & 160 & 180 & 125 & 80 & 100 & 100 & 190 & 150 \\
\hline & Plain (km) & $<2$ & $3-15$ & 3 & $15-20$ & $15-20$ & -- & -- & -- & -- \\
\hline
\end{tabular}

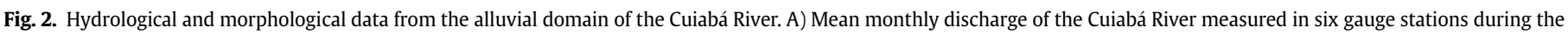

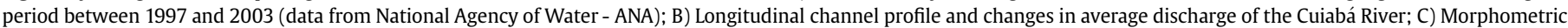
parameters of the Cuiabá river channel. Location of gauge stations and morphological reaches shown on Fig. 3.

channel morphology. Hydrological data from six gauge stations were obtained from the Brazilian National Agency of Water (ANA). Satellite images (optical and radar) were used to interpret channel patterns and floodplain landforms, using parameters such as the channel sinuosity (SI) and width, and channel and floodplain slope. The chronological framework was determined using OSL dating applied to quartz sand grains. The OSL and radiocarbon ages within the Cuiabá megafan presented in previous studies (Beirigo, 2013; Fonseca, 2015; Zaparoli, 2015) were used for regional stratigraphic correlation.

\subsection{Remote sensing and geomorphological zonation}

Regional geomorphological mapping was performed using georeferenced images of Landsat $5 \mathrm{TM}$ (resolution $30 \mathrm{~m}$ ) and GeoCover 2000 (resolution $15 \mathrm{~m}$ ) from USGS Global Visualization Viewer (GLOVIS). Digital image processing techniques were applied on Landsat TM images. False-color composite 743 (RGB) and selective principal component analysis (SPCA) by fusion PC1 of bands 1, 2 and $3(\mathrm{R})$; band $4(\mathrm{G})$; and PC1 of bands 5 and 7 (B) (Chavez and Kwarteng, 1989) were especially useful to extract a better spectral contrast in a false-color image and for the enhancement of fluvial landforms. Furthermore, images from the SPOT 5 satellite (resolution $2.5 \mathrm{~m}$ ) were used to improve the remote sensing interpretation of smaller geomorphic features.

Shuttle Radar Topography Mission (SRTM) products with 3 arcsecond resolution (nominally $90 \mathrm{~m}$ ) were used to design the digital elevation model (DEM). To enhance SRTM-DEM, the technique proposed by Zani et al. (2012) was applied. The global topography was calculated and found to be accurately represented by a second order polynomial function. Simple subtraction of the global topography from altitude produced a new DEM, the residual elevation model (REM), which greatly enhanced low-amplitude landforms within the Cuiabá Modern Fan. Shade scheme and palettes were customized for both DEMs, further highlighting lowamplitude landforms, such as avulsion deposits, paleochannel belts and lobate landforms. The SRTM-DEM absolute height error is $9 \mathrm{~m}$ for South America and can be lower than $5 \mathrm{~m}$ in low-relief terrains (Rodríguez et al., 2006). However, caution should be taken when interpreting an SRTM-DEM on low-relief terrains, since the vegetation can be a potential source of error due to $C$ band sensor sensitivity to land cover that might identify artificial heights induced by densely forested areas (Valeriano et al., 2006) and local terrain model inversions (LaLonde et al., 2010). Nevertheless, the dense and tall vegetation (wooded savanna) of the Pantanal is usually located in elevated areas with well-drained soils (Prance and Schaller, 1982), and these are correctly represented by an even higher elevation in the enhanced DEM (Zani et al., 2012).

Geomorphic zones were defined by drainage networks, depositional landforms and channel pattern analysis. Drainage networks and depositional landforms were mapped using visual satellite image interpretation. Morphometric characterization and elevation profiles were derived from SRTM-DEM and REM.

\subsection{Field sampling and validation}

One overflight and four field campaigns were carried out from 2011 to 2012 for the characterization and validation of geomorphic

Table 1

SAR-OSL protocol used for equivalent dose estimation of the studied samples.

\begin{tabular}{ll}
\hline Step & Procedure \\
\hline 1 & Dose $\left(\mathrm{D}_{\mathrm{i}}\right)^{\mathrm{a}}$ \\
2 & Preheat at $200{ }^{\circ} \mathrm{C}$ for $10 \mathrm{~s}$ \\
3 & OSL at $125^{\circ} \mathrm{C}$ for $40 \mathrm{~s}\left(\mathrm{~L}_{\mathrm{i}}\right)$ \\
4 & Test dose \\
5 & Heat at $160{ }^{\circ} \mathrm{C}$ \\
6 & OSL at $125{ }^{\circ} \mathrm{C}$ for $40 \mathrm{~s}\left(\mathrm{~T}_{\mathrm{i}}\right)$ \\
7 & Blue LEDs bleach at $280{ }^{\circ} \mathrm{C}$ for $40 \mathrm{~s}$ \\
8 & Return to step 1 \\
\hline
\end{tabular}

${ }^{a}$ For measurement of the natural signal, Di $=0$ Gy. Regeneration doses Di: D1 $<\mathrm{D} 2<\mathrm{D} 3<\mathrm{D} 4 ; \mathrm{D} 5=0 \mathrm{~Gy}, \mathrm{D} 6=\mathrm{D} 1$; D7 = D6, with additional infrared stimulation before blue stimulation for OSL measurement of D7. The test dose is kept constant throughout the SAR sequence. A corrected luminescence signal was calculated through the ratio between $\mathrm{Li}$ and $\mathrm{Ti}$. OSL signal was calculated using the integral of the first $0.8 \mathrm{~s}$ of light emission with subtraction of the normalized last $10 \mathrm{~s}$ of light emission as background. 


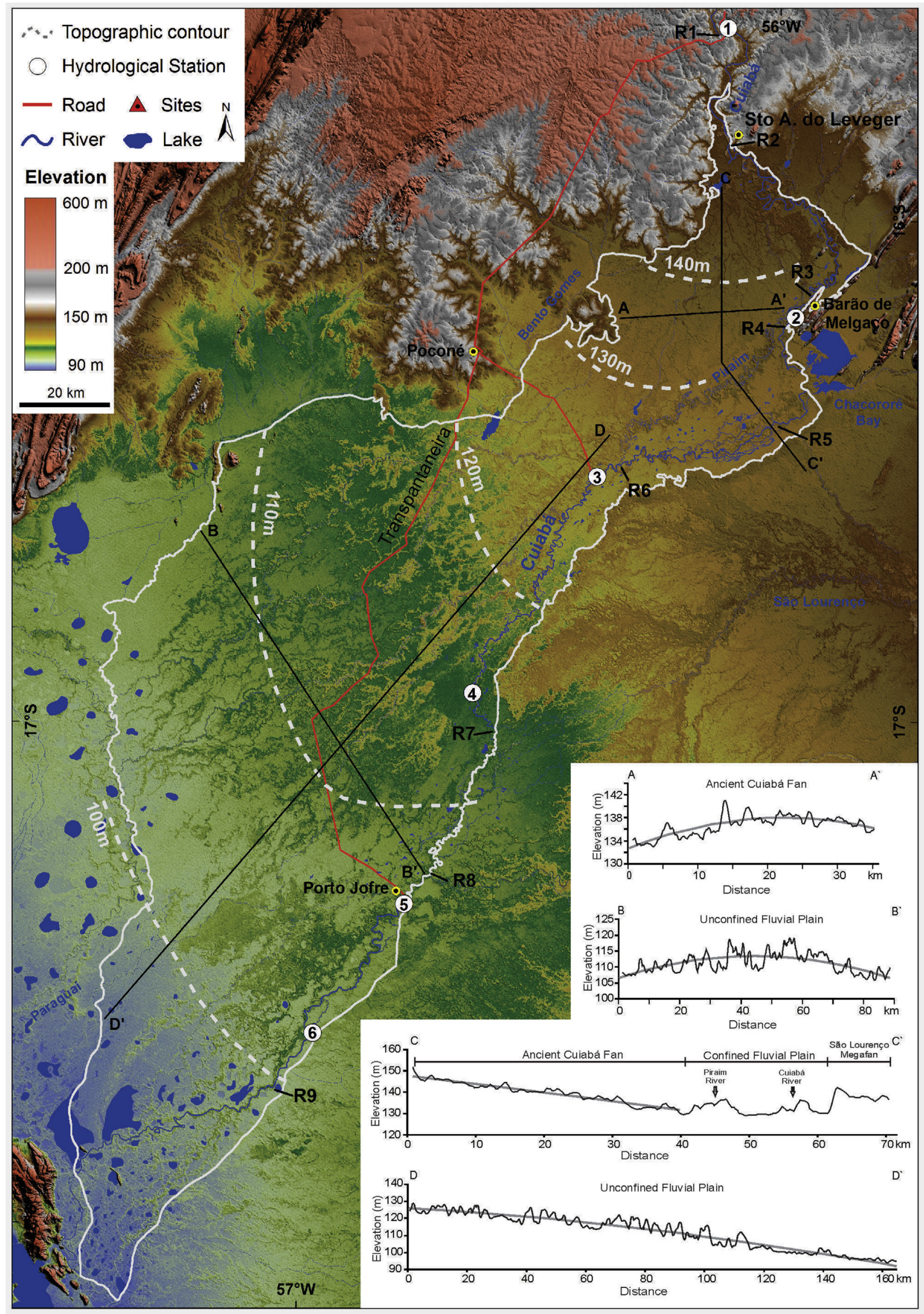




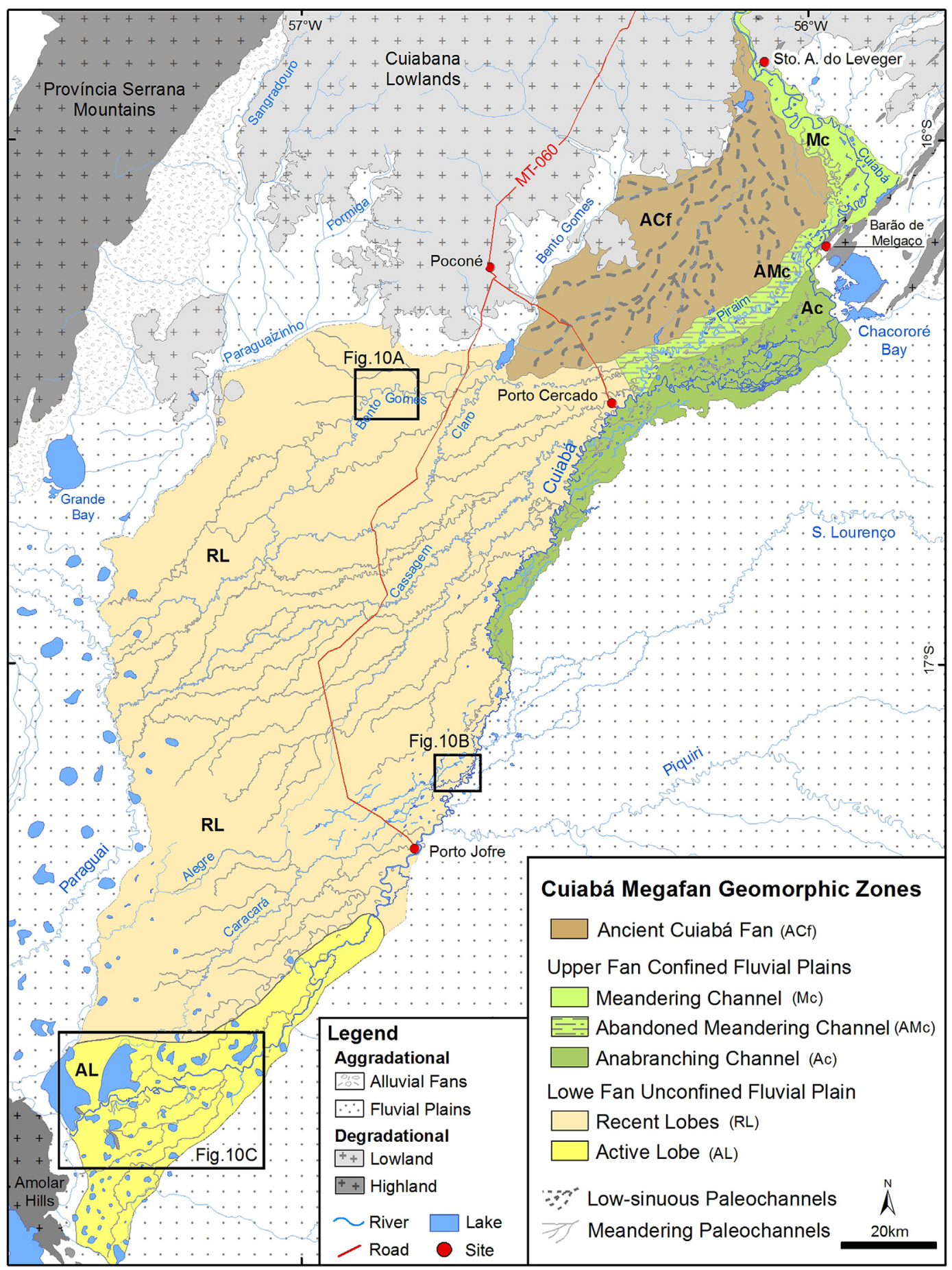

Fig. 4. Geomorphological map of the Cuiabá fluvial megafan.

features recognized through the analysis of satellite images. Over the course of these expeditions, surface depositional features and subsurface sedimentary facies were described and sampled through coring and trenches. Four sediment cores were recovered from paleochannels of an ancient fan at depths ranging between 1.5 and $1.7 \mathrm{~m}$. OSL dating was performed on sediment samples recovered from the base of each core. This sampling strategy was defined to determine the age and period of activity of each paleochannel. One additional sample was recovered from the adjacent floodplain at the proximal sector of the fan at a depth of $0.3 \mathrm{~m}$ to

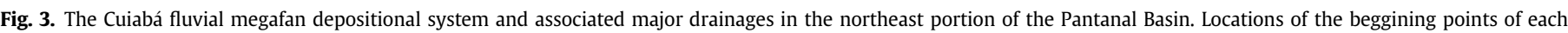

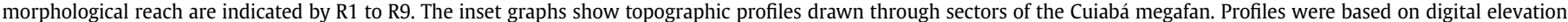

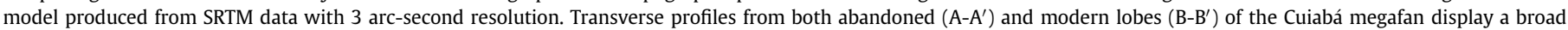
convex-up surface superposed by smaller stacked segments related to paleochannels. Longitudinal profiles $\left(C-C^{\prime}\right.$ and $\left.D-D^{\prime}\right)$ display the very low overall surface gradient. 
assess the potential for surface sediment reworking on the ancient landform.

\subsection{Luminescence dating}

OSL dating was performed on quartz sand grains at the Luminescence and Gamma Spectrometry Laboratory (LEGaL), Institute of Geosciences of the University of São Paulo (USP). Samples were wet-sieved to isolate the $180-250 \mu \mathrm{m}$ grain-size fraction. The target fraction was treated with hydrogen peroxide $\left(\mathrm{H}_{2} \mathrm{O}_{2}, 27 \%\right)$ and hydrochloric acid $(\mathrm{HCl}, 3.7 \%)$ to remove organic matter and carbonate minerals, respectively. Heavy mineral $\left(>2.75 \mathrm{~g} / \mathrm{cm}^{3}\right)$ and feldspar $\left(<2.62 \mathrm{~g} / \mathrm{cm}^{3}\right)$ grains were removed by heavy liquid separation with a lithium metatungstate solution. Then, quartz concentrates $\left(2.62-2.75 \mathrm{~g} / \mathrm{cm}^{3}\right)$ were etched with hydrofluoridric acid (HF, 40\%) for $40 \mathrm{~min}$ to remove remnant feldspar grains and etch a $\sim 10 \mu \mathrm{m}$ outer layer of quartz grains, thus removing the alpha particles contribution from the radiation dose rate.

Aliquots of quartz grains (100-200 grains) were mounted on stainless steel cups for luminescence measurements on an automated Risø TL/OSL DA-20 reader system equipped with a ${ }^{90} \mathrm{Sr} /{ }^{90} \mathrm{Y}$ beta source that delivered a dose rate of $0.084 \mathrm{~Gy} / \mathrm{s}$, blue LEDs $(470 \pm 20 \mathrm{~nm})$ operated at $90 \%$ power $(\sim 40 \mathrm{~mW} / \mathrm{cm})$ for stimulation and a Hoya U-340 filter for light detection in the ultraviolet band (290-340 nm) with a bialkali PM tube (Thorn EMI 9635QB). The single aliquot regenerative dose (SAR) protocol (Murray and Wintle, 2000,2003 ) was applied to estimate the radiation equivalent doses (Table 1). A dose recovery test was performed with six quartz aliquots, a pre-heat temperature of $200{ }^{\circ} \mathrm{C}$ and a given dose of $6.7 \mathrm{~Gy}$. Only aliquots with recycling ratio values between 0.90 and 1.10 , recuperation of less than $5 \%$ and a negligible feldspar signal tested by infrared stimulation were used in the equivalent dose calculations, as suggested by Murray and Wintle $(2000,2003)$. Equivalent doses were calculated using the central age model (Galbraith et al., 1999).

Radionuclides concentrations for the dose rate calculations were determined by gamma ray spectrometry using a high-purity germanium (HPGe) detector that had a 55\% relative efficiency and $2.1 \mathrm{keV}$ energy resolution and encased in an ultralow background shield (Canberra Industries). Each sample was dried and packed in sealed plastic containers and stored for at least 28 days to allow radon to reach equilibrium with its parent radionuclides prior to the gamma spectrometry measurement. The beta and gamma radiation dose rates were determined using the radionuclides concentrations ( $\mathrm{U}$, Th and $\mathrm{K}$ ) and conversion factors outlined by Guérin et al. (2011). Water saturation was determined by the ratio between water weight and dry sample weight. The cosmic dose rate contribution was calculated using the sample depth, elevation, latitude and longitude as described by Prescott and Hutton (1994).

\section{Geomorphological zonation and channel patterns}

The Cuiabá River is $1080 \mathrm{~km}$ long and runs in two distinct domains: a $510 \mathrm{~km}$ course in the catchment area dominated by bedrock substrates and a $570 \mathrm{~km}$ course in the Pantanal alluvial plain. The catchment has an area of $22,000 \mathrm{~km}^{2}$ and mainly consists of gently sloping low-grade metamorphic rocks, mostly represented by phyllites, quartzites and limestones, which source finegrained sediments to the Pantanal sedimentary basin. The alluvial domain is developed entirely within the Pantanal wetland, where the Cuiabá River forms a large depositional system that covers as much as $15.300 \mathrm{~km}^{2}$ (Fig. 3). The Cuiabá system coalesces with the São Lourenço and Taquari megafans to the east and southeast.

Abandoned depositional lobes are closely located along the wetland border in the upper portion of the megafan. These abandoned lobes have preserved low-sinuosity distributary paleochannels and relatively high elevation in relation to the modern depositional areas, and they record the sedimentary dynamics of the ancient Cuiabá fan, which is presently dominated by processes of degradation and weathering. In the active depositional setting, differences in channel morphology allow the subdivision of the modern Cuiabá megafan into two geomorphic zones: (1) fluvial plains with meandering and anabranching channel patterns developed within an entrenched valley in the upper megafan setting and (2) unconfined floodplains in the distal fan portion, with modern lobes formed by a single sinuous channel that turns into a distributive channels network downstream (Fig. 4).

\subsection{Ancient fan}

The ancient fan covers $\sim 1900 \mathrm{~km}^{2}$ at the proximal sector of the Cuiabá megafan. The fan apex was near the modern course of the Cuiabá River at its entrance into the wetland, and the fan grew southward with a radial paleoflow pattern forming sand-grained sediment lobes. The surface shows concentric contour lines radiating to the distal part (Fig. 3). The transverse west-east cross profile drawn through the center of the fan displays a convex-up morphology (Fig. 3, profile A-A'), whereas the longitudinal northsouth cross profile reveals a low-gradient slope of $31 \mathrm{~cm} / \mathrm{km}$ (Fig. 3, profile C-C'). The ancient fan is topographically higher than the modern Cuiabá River plains. Flood inundation due to surface runoff during the wet period (November to March) is commonly brief and only a few centimeters $(<30 \mathrm{~cm})$ of water depth.

Paleochannels are remarkable features on the surface of the ancient fan that can be easily recognized in remote sensing imagery (Fig. 5). In a plan view, relict channels exhibit a semi-radial distributary network that bifurcate and divert downstream into narrower channels (Fig. 6A). These paleochannels display low sinuosity $(\sim 1.2)$, forming elevated channel ridges that are approximately $1.5 \mathrm{~m}$ higher than the adjacent flood basin (Figs. 5 and 7B).

Shallow sediment cores (1.6-1.9 $\mathrm{m}$ depth) retrieved from paleochannels generally consist of fine to very fine quartz sands with scattered granules. Cross stratification can be present, but the sands are dominantly massive with incipient development of mottles and nodules of iron oxide (Fig. 7A). The only exception was the core from a paleochannel in the proximal part of the ancient fan, with massive silt and clay beds, with red, yellow and gray colors due to the mottling and plinthite development (Fig. 7A). OSL dating of samples from bottom sand layers of cores 01, 02 and 04 retrieved in three paleochannels in the proximal and intermediate fan settings yielded ages of $19.8 \pm 3.2 \mathrm{ka}, 20.6 \pm 2.1 \mathrm{ka}$ and $21.1 \pm 3.5 \mathrm{ka}$, respectively. An older age of $49.2 \pm 6.0$ ka resulted from sediments of a paleochannel at the distal part of the ancient fan (core 03, Table 2). The equivalent doses have low to moderate overdispersion (21-41\%), indicating relatively well-bleached sediments without evidence of significant post-depositional mixing.

Most of the ancient Cuiabá fan surface is presently undergoing a degradation process due to erosion by groundwater-fed streams (plains-fed sense Sinha and Friend, 1994) developed from the central to distal portion of the fan (Fig. 5). These small streams form a tributary network, mostly with an intermittent flux and typically underfit streams (Fig. 6A). Sediment erosion and reworking that took place after fan abandonment are responsible for the existence of a thin veneer of sediments covering older deposits. Such is the case for deposits sampled in the flood basin between the elevated channel ridges (adjacent to the core 04). These deposits comprise massive reddish very fine sand and mud and revealed a relatively young OSL age of $6.7 \pm 0.9 \mathrm{ka}$ (sample BRC-19, Table 2). 


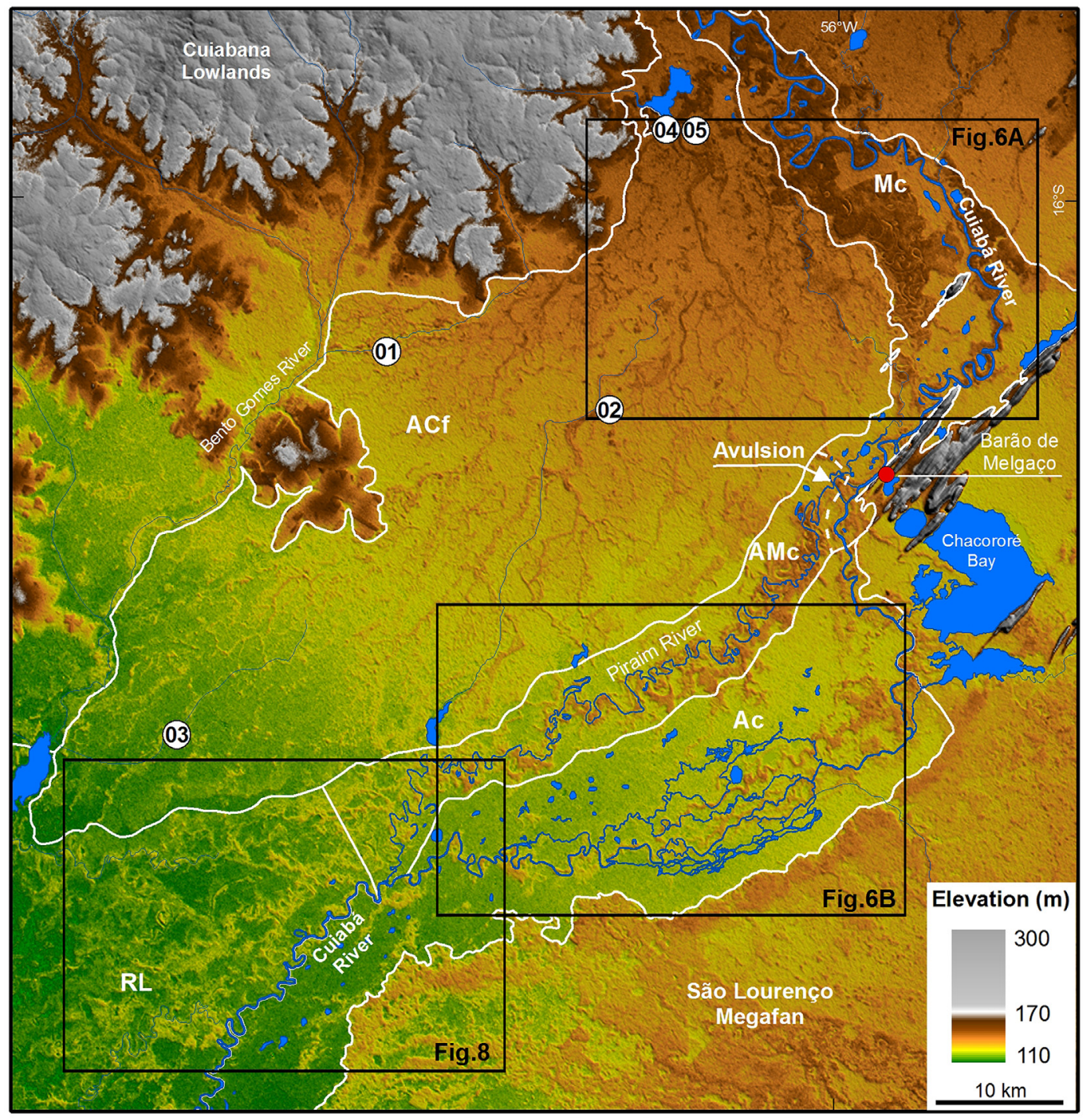

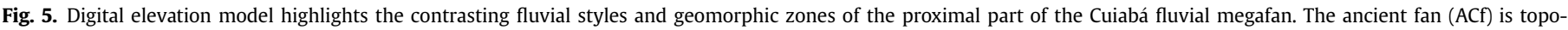

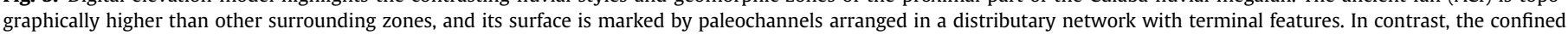

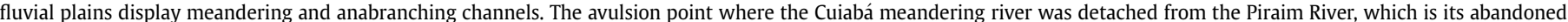

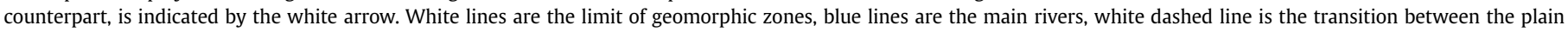

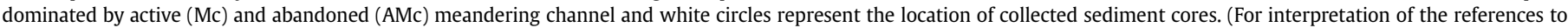
colour in this figure legend, the reader is referred to the web version of this article.)

\subsection{Modern fan}

The apex of the modern Cuiabá megafan coincides with the point at which the Cuiabá River emerges from a dissected metamorphic terrain in the Cuiabana lowlands and enters the Pantanal near the town of Santo Antônio do Leveger (northeast, Fig. 3). The longitudinal NE-SW profile is approximately $300 \mathrm{~km}$ from the apex to the fringe of the megafan, where the Cuiaba River reaches the Paraguay River plain. At the regional scale, contour lines extracted from the DEM exhibit a concentric pattern centered on the apex of the system, configuring a large fan-shaped morphology, covering approximately $13,400 \mathrm{~km}^{2}$ (Fig. 3).

The longitudinal profile of the Cuiabá River shows elevations that vary from 155 m.a.s.l. at the apex to 95 m.a.s.l at the fan fringe and exhibits a concave up smooth low-gradient shape (Fig. 2B). The surface is almost flat, with an average slope of $11 \mathrm{~cm} / \mathrm{km}$ on the channel and $20 \mathrm{~cm} / \mathrm{km}$ on the plain. Despite the relief monotony, there are many changes in the surface morphometric parameters of the fluvial features, such as the channel sinuosity, width and slope (Fig. 2C).

\subsubsection{Confined fluvial plains in the upper fan}

The Cuiabá River is a bedrock river upstream from its entrance into the Pantanal wetland (reach 1, Figs. 2B and 3). Downstream, the channel slope and width decrease abruptly (reach 2, Fig. 2C) and the river begins to flow in a large plain valley entrenched between alluvial deposits of the ancient fan to the west and metamorphic rocks that crop out to the east. Downstream, the upper fan entrenched valley is similar to an interfan system because the fluvial plain is confined by the ancient Cuiabá fan (west) and São Lourenço megafan (east). The valley is $100 \mathrm{~km}$ in length and $3-20 \mathrm{~km}$ wide, and it is interpreted as an upper fan confined fluvial plain (Fig. 4).

The Cuiabá River displays a meandering pattern in reach 2 , where the floodplain width varies from 3 to $15 \mathrm{~km}$, but the sinuosity varies from 1.2 to 1.8 and, in short segments, the channel is 

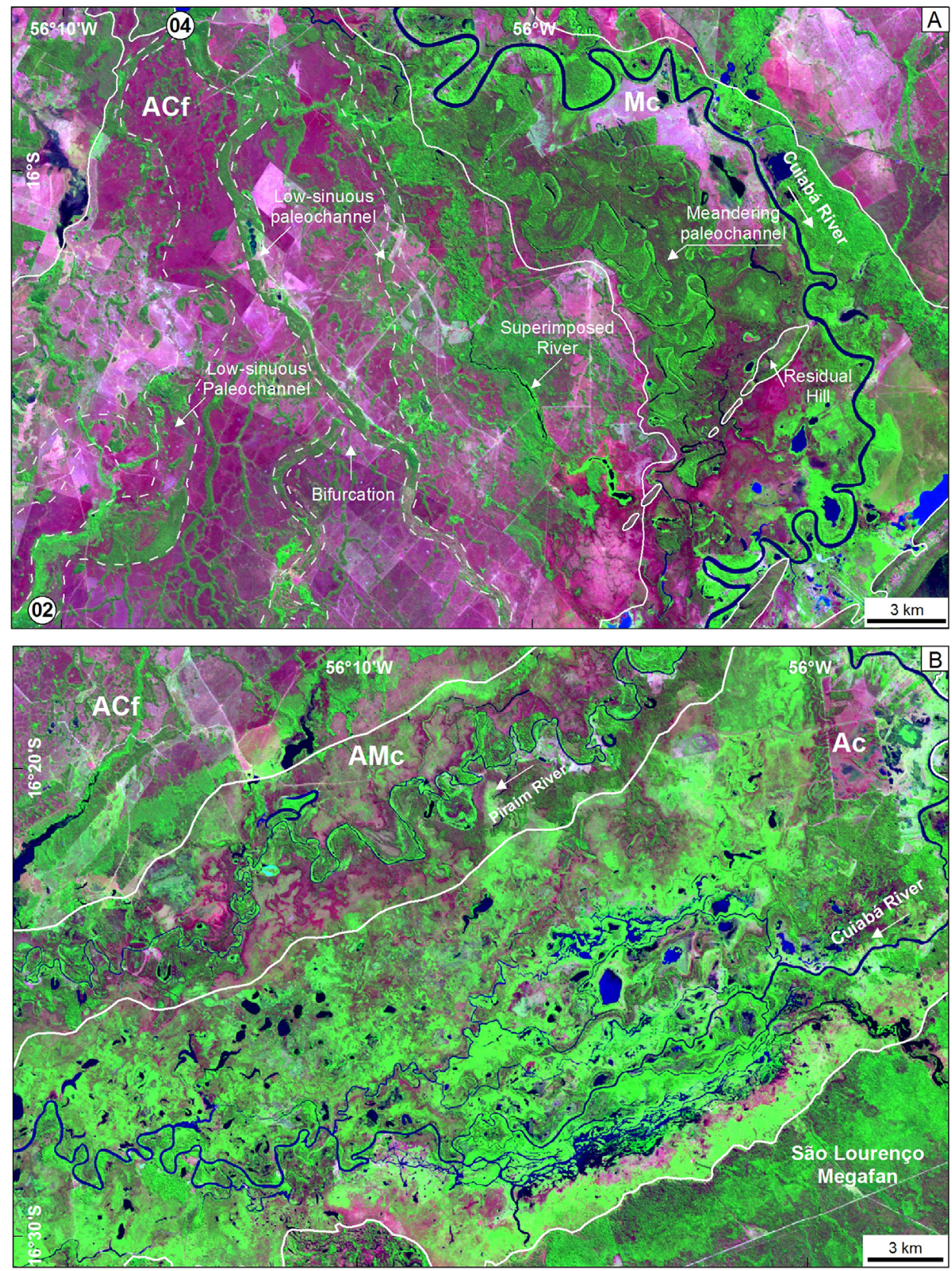

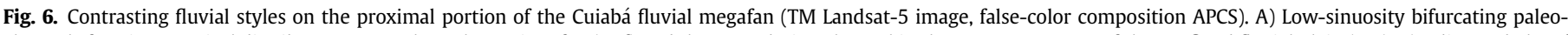

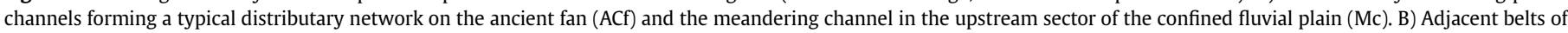
meandering (AMc) and anabranching channels (Ac) in the downstream sector of the confined fluvial plain (location on Fig. 5).

straight (Fig. 6A). Scroll bars and oxbow lakes are dominant depositional landforms in the floodplain surrounding the active river channel. An abandoned channel is recognized on the right border of the floodplain, with a sinuosity and width very similar to those of the active channel. Those forms indicate that meander cutoff and partial avulsion are fundamental processes to the confined floodplain evolution. When the Cuiabá River reaches the hills of Barão de Melgaço (reach 3, Fig. 3), the channel deflects $90^{\circ}$ southwest and the floodplain width narrows from 15 to $3 \mathrm{~km}$, suggesting structural control by aligned hills of metamorphic rocks (Fig. 8A). The monthly average discharge is similar between Cuiabá and Barão de Melgaço ( $340 \mathrm{~m}^{3} / \mathrm{s}$ and $357 \mathrm{~m}^{3} / \mathrm{s}$, respectively; Fig. 2B) due to balanced water output to the floodplain and input from the three small tributaries on the left bank.
Major changes in the channel pattern occur downstream of the Barão de Melgaço station (Fig. 3). The channel slope and width decrease and the floodplain becomes wider in reaches 4 and 5 (Fig. 2C). The main channel of the Cuiabá River flows along the left margin of the floodplain, where the river assumes an anabranching pattern characterized by sinuous channels and stable alluvial islands that divide the flows at discharges up to bankfull (in the sense of Nanson and Knighton, 1996). The floodplain and islands stand at approximately the same elevation, displaying numerous circular ponds, oxbow lakes, paleochannels and crevasse splays, indicating channels with lateral migrations and frequent avulsions. Meanwhile, the meander belt extends over $50 \mathrm{~km}$ on the right side of the floodplain (Fig. 6B). The modern channel is called the Piraim River, a channel that is $30 \mathrm{~m}$ wide and has low water discharge, 

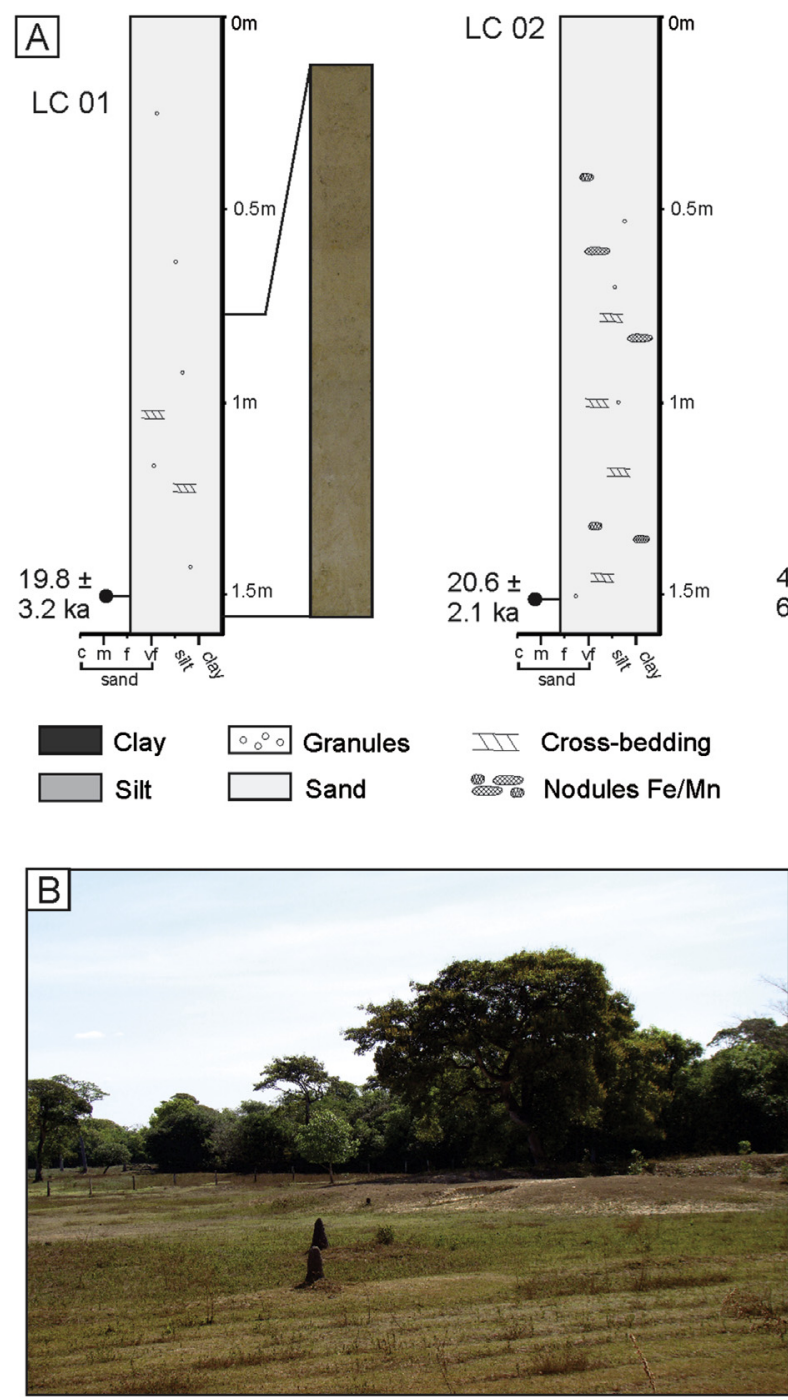
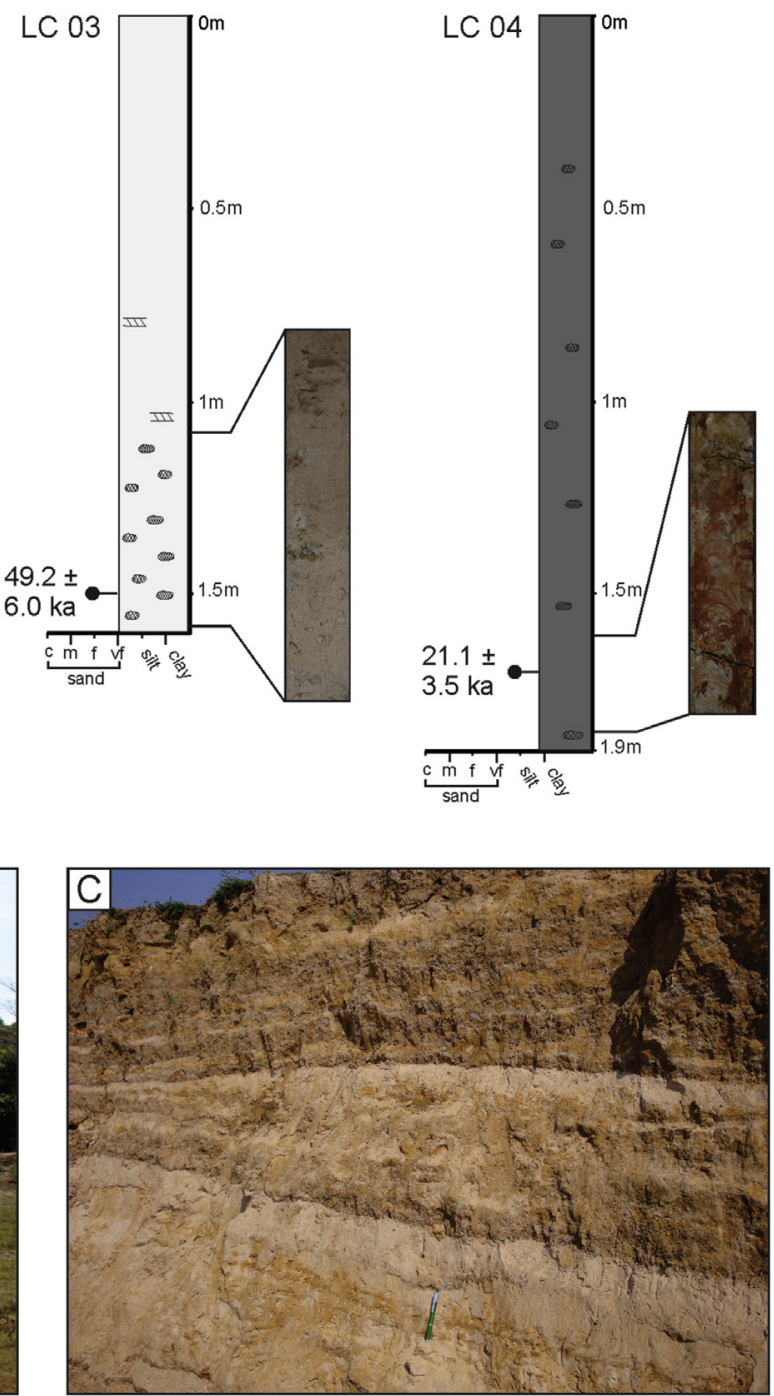

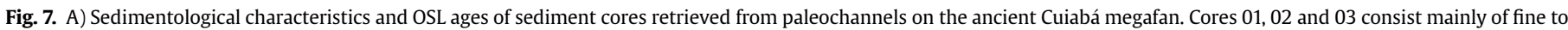

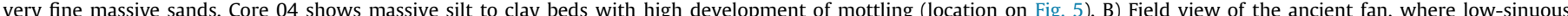

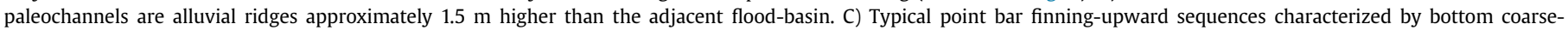
grained sand capped by fine-grained sediments (silt and clay). This is the dominant sedimentary facies association in the upper fan confined fluvial plains.

Table 2

Equivalent doses, dose rates and OSL ages for the studied samples from the Cuiabá fluvial fan.

\begin{tabular}{|c|c|c|c|c|c|c|c|c|c|c|c|c|c|}
\hline $\begin{array}{l}\text { Sample } \\
\text { ID }\end{array}$ & $\begin{array}{l}\text { UTM } \\
\text { (Long//Lat) }\end{array}$ & $\begin{array}{l}\text { Elev. } \\
(\mathrm{m})\end{array}$ & $\begin{array}{l}\text { Depth } \\
(\mathrm{m})\end{array}$ & $\mathrm{U}(\mathrm{ppm})$ & Th (ppm) & $\mathrm{K}(\%)$ & $\begin{array}{l}\text { Cosmic dose } \\
\text { rate }(\mathrm{Gy} / \mathrm{ka})\end{array}$ & $\begin{array}{l}\text { Water } \\
\text { sat. (\%) }\end{array}$ & $\begin{array}{l}\text { Total Dose } \\
\text { rate }(\mathrm{Gy} / \mathrm{ka})\end{array}$ & $\begin{array}{l}\text { Equivalent } \\
\text { dose (Gy) }\end{array}$ & $\mathrm{N}$ & OD (\%) & $\begin{array}{l}\text { OSL age } \\
\text { (ka) }\end{array}$ \\
\hline BRC-03 & $\begin{array}{l}571487 / / \\
8218765\end{array}$ & 141 & 1.5 & $0.603 \pm 0.022$ & $1.883 \pm 0.063$ & $0.082 \pm 0.005$ & $0.175 \pm 0.014$ & 2 & $0.529 \pm 0.033$ & $10.5 \pm 1.5$ & 24 & $39 \pm 11$ & $19.8 \pm 3.2$ \\
\hline BRC-06 & $\begin{array}{l}588875 / / \\
8214098\end{array}$ & 144 & 1.5 & $0.492 \pm 0.020$ & $1.769 \pm 0.062$ & $0.047 \pm 0.004$ & $0.175 \pm 0.014$ & 2 & $0.460 \pm 0.028$ & $9.5 \pm 0.7$ & 22 & $21 \pm 6$ & $20.6 \pm 2.1$ \\
\hline BRC-14 & $\begin{array}{l}555024 / / \\
8188666\end{array}$ & 134 & 1.5 & $0.923 \pm 0.027$ & $3.353 \pm 0.090$ & $0.141 \pm 0.007$ & $0.175 \pm 0.014$ & 2 & $0.765 \pm 0.051$ & $37.6 \pm 3.8$ & 15 & $27 \pm 7$ & $49.2 \pm 6.0$ \\
\hline BRC-16 & $\begin{array}{l}593628 / / \\
8236358\end{array}$ & 148 & 1.7 & $1.446 \pm 0.039$ & $9.193 \pm 0.195$ & $0.783 \pm 0.024$ & $0.171 \pm 0.013$ & 18 & $1.653 \pm 0.107$ & $34.9 \pm 5.4$ & 16 & $41 \pm 11$ & $21.1 \pm 3.5$ \\
\hline BRC-19 & $\begin{array}{l}595553 / / \\
8236485\end{array}$ & 146 & 0.3 & $1.379 \pm 0.057$ & $7.356 \pm 0.276$ & $0.379 \pm 0.018$ & $0.205 \pm 0.037$ & 13 & $1.279 \pm 0.089$ & $8.6 \pm 1.0$ & 15 & $31 \pm 8$ & $6.7 \pm 0.9$ \\
\hline
\end{tabular}

$\mathrm{N}$ is the number of aliquots; OD is the overdispersion of equivalent doses distributions.

water flux velocity and sediment yield. However, the dimension and morphology of this meander belt are similar to those of the upper portion of the Cuiabá River, where paleochannels and oxbow lakes are approximately $100 \mathrm{~m}$ in width (Fig. 6B). Thus, the Piraim River is an underfit channel within the abandoned floodplain.
Many different facies associations are exposed along the river embankments due to erosion by the lateral migration of the channel, including typical point bar finning-upward sequences beginning with coarse-grained sand and capped by fine-grained facies, exhibiting lateral accretion surfaces and overbank deposits 


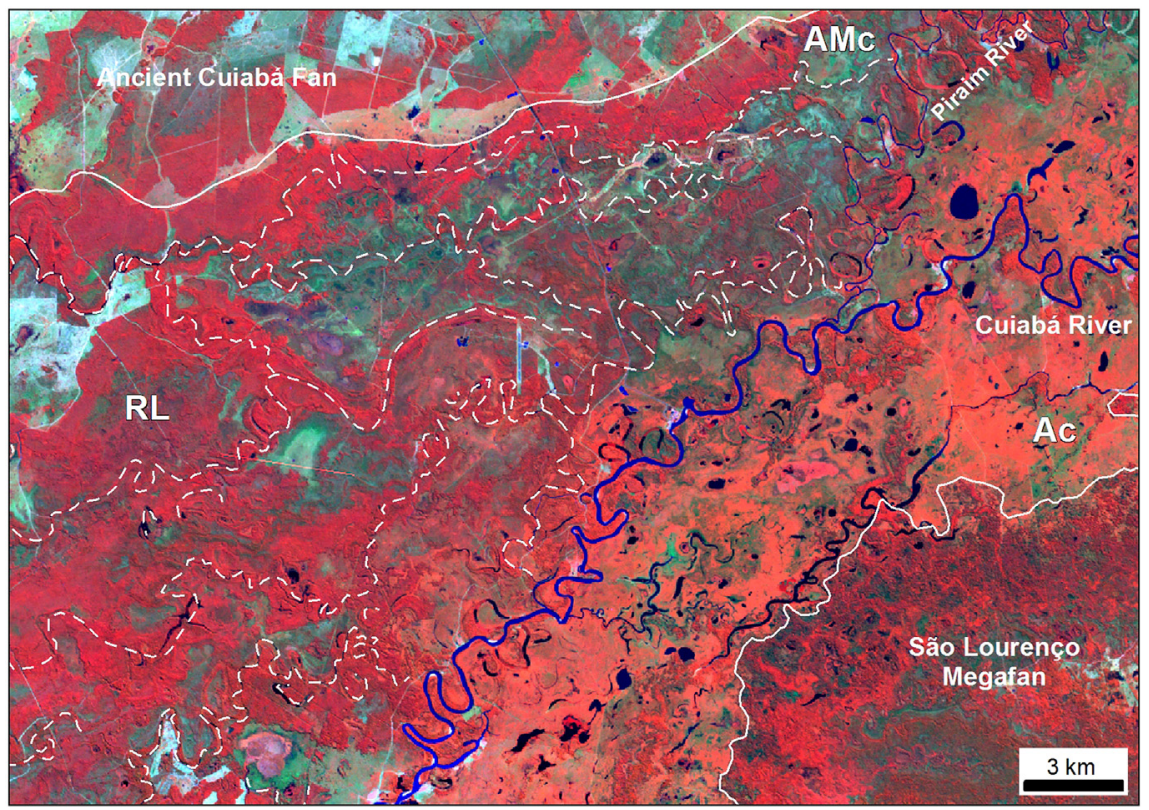

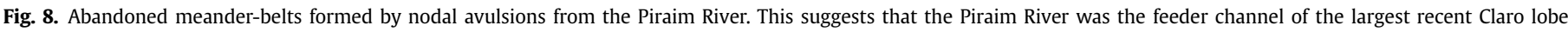
(location on Fig. 5; TM Landsat-5 image, false-color composition APCS).

(Fig. 7C). Two sediment samples collected 4-5 m deep in deposits of the floodplain area (reach 5) yielded radiocarbon ages of 8540 (Beirigo, 2013) and 8710 years BP (Zaparoli, 2015), indicating that fluvial aggradation in the upper fan confined plains has been occurring at least since the early Holocene.

The Cuiabá and Piraim Rivers join to a single channel downstream in the beginning of reach 6 (Fig. 3), where the channel switches to a single-meandering pattern with a sinuosity index of 1.8. It is remarkable that the Cuiabá River forms a prominent alluvial ridge that is approximately $1 \mathrm{~m}$ above the adjacent floodplains, dividing the surface waters flowing from the Cuiabá unconfined floodplain (west) and the São Lourenço distal fan (east). On the eastern side of the floodplain, there are small lakes and sinuous paleochannels that connect with the active channel during the wet season, indicating that the multichannel pattern can be traced downstream up to the confluence with the São Lourenço River (Fig. 8).

The mean annual water discharge decreases from $357 \mathrm{~m}^{3} / \mathrm{s}$ in Barão de Melgaço to $288 \mathrm{~m}^{3} / \mathrm{s}$ at the Porto Cercado gauge station (Fig. 2A), reflecting a significant loss of water to the floodplain in the anabranching river reach. Water flow during the dry season is restricted to the main channel, while the floodplain is completely flooded during the wet season. Fantin-Cruz et al. (2011) documented that the median flood events (return period of 2 years) produce an average water depth of $1.80 \mathrm{~m}$ in floodplains for four months of the year, but the water depth can reach $2.6 \mathrm{~m}$ in extreme flood events.

\subsubsection{Unconfined fluvial plains in the lower fan}

The unconfined floodplain dominates the central and distal portions of the Cuiabá megafan, an active depositional setting that covers $11.800 \mathrm{~km}^{2}$ and is cauterized by the presence of distributary fan lobes (Fig. 4). Its apex is at the output of the confined plains, and the distal fringe abuts in the Paraguay floodplain. The floodplain becomes wider (increasing from 20 to $100 \mathrm{~km}$ ) and unconfined, and numerous sinuous paleochannels are still preserved on the surface. The Cuiabá River is the feeder channel, which undergoes a continuous decrease in width and discharge to downstream (reach
6 to 9) due to the loss of water to the floodplain by avulsion, overflow, infiltration and evaporation, becoming a low sinuosity channel (Fig. 2B). The widening of the channel in reach 8 is an exception to this downstream trend because the Cuiabá River receives the flow of São Lourenço $\left(265 \mathrm{~m}^{3} / \mathrm{s}\right)$ and Piquiri $\left(296 \mathrm{~m}^{3} / \mathrm{s}\right)$ and the discharge shoots up to $777 \mathrm{~m}^{3} / \mathrm{s}$ at the Porto Taimã gauge stage. The absence of downstream tributaries and the loss of water to the floodplain drive the decrease of water discharge in the lower reaches of the Cuiabá River (Fig. 2B).

The regional topography is characterized by a gentle gradient

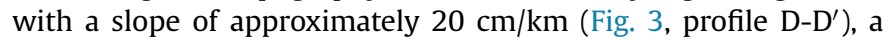
convex up cross-profile (Fig. 3, profile B-B') and a radial geometry highlighted by concentric contour lines (Fig. 3). This wide low-slope topography provides a horizontal accommodation space to channel lateral migration. Observations of satellite images show a paleochannel network imprinted on the plain surface. However, several channels overlap and truncations, as well as the current runoff dynamics that mask and obliterate relict landforms landscape, hinder the mapping and reconstruction of this paleodrainage system (Fig. 3). Digital image processing applied to SRTM-DEM and REM allowed the enhancement of depositional landforms and the recognition of three distinct drainage systems (Fig. 9). The recently abandoned Claro and Caracará lobes were identified at the proximal and central portions of the unconfined plain, while the modern lobe has been built on the distal border (Figs. 4 and 9).

The paleochannels are characterized as single meander belts arranged in a distributary network overlapping an old alluvial surface in the Claro lobe (Fig. 10A). Most of these paleochannels begin at the ends of the confined fluvial plain, where nodal avulsions were recognized (Fig. 8). The apex of the Caracará lobe is at the confluence of the Cuiabá and Piquiri Rivers. The paleodrainage system is obliterated by dense vegetation cover and degradation by surface erosional processes, such as sheet flows and pluvial erosion. However, it is possible to observe that the paleochannels comprise sinuosity channels that are arranged in a distributary network (Fig. 9). In addition to the paleochannels, several streams drain the floodplain. These streams are plains-fed type, and they are typically underfit in larger abandoned meander belts that represent a 

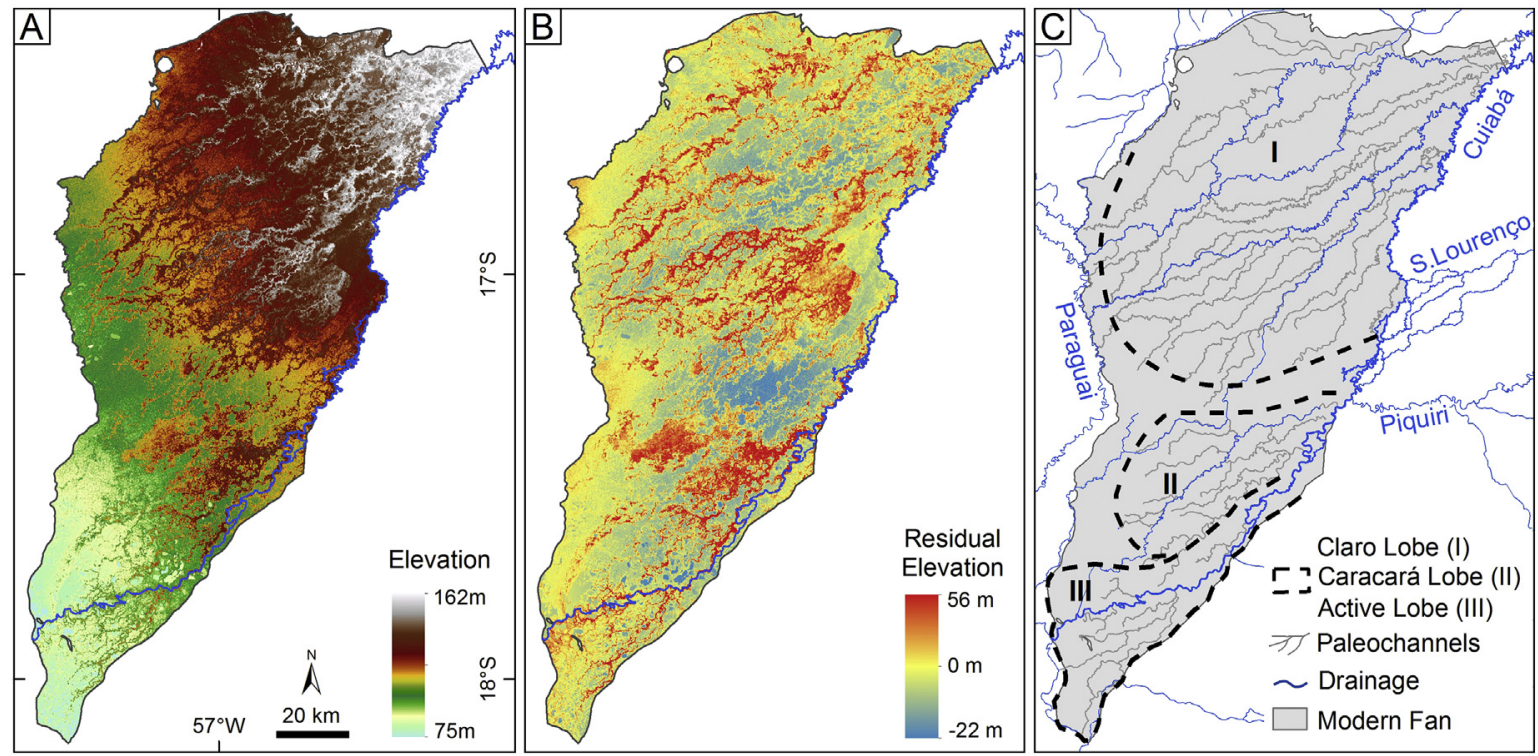

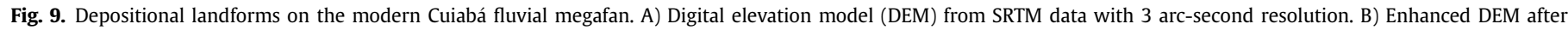

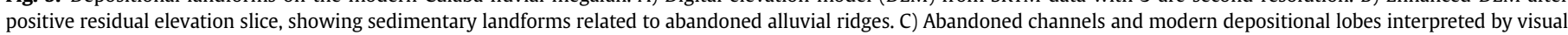
analysis from the enhanced DEM.
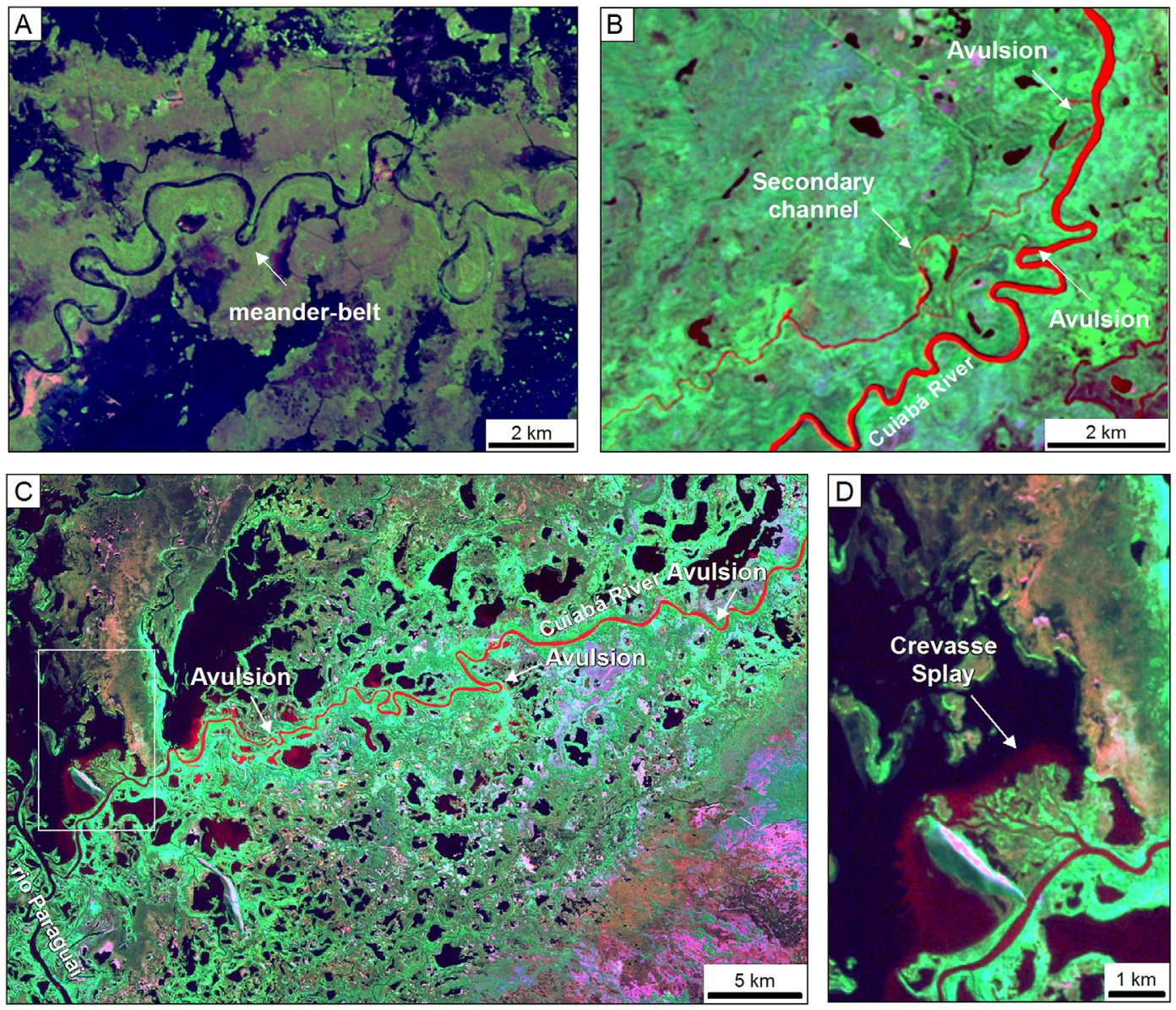

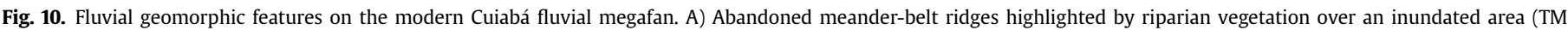

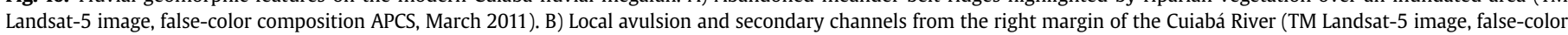

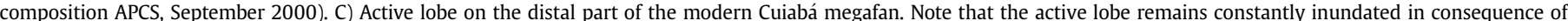

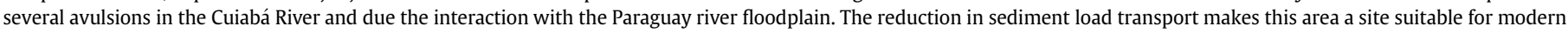

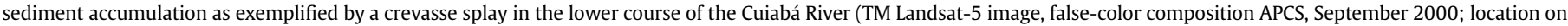
Fig. 4). 
previous position of the main river channel on the system.

In the active lobe (reach 9), the Cuiabá River channel becomes narrower, with low sinuosity (Fig. 2C). Many crevasses and avulsion nodes along the main and secondary channels supply water and sediments to a constantly inundated floodplain (Fig. 10C). Several small lakes in the floodplain accumulate a large amount of water diverted from the Cuiabá River and act as the main sink for sediments in the lower unconfined floodplain.

\section{Changes in the sedimentary dynamics of the Cuiabá fluvial megafan}

Geomorphological mapping based on channel morphology, truncation and superposition by paleochannels and active channels allowed the characterization of depositional landforms and the establishment of a relative succession of events that formed the landscape of the Cuiabá megafan. The chronological framework of the interpreted geomorphic changes resulted from OSL dating and stratigraphic correlations with previous data from the Cuiabá megafan (Beirigo, 2013; Fonseca, 2015; Zaparoli, 2015). Available information of the coalescing Taquari (Assine and Soares, 2004; Zani et al., 2012), Paraguay (Assine and Silva, 2009) and São Lourenço (Assine et al., 2014) fluvial megafans were analyzed to reconstruct the paleoenvironmental scenario.

Three main phases of fluvial fan development were recognized: a) an aggradational phase that built up the abandoned lobes in the upper fan portion during the Late Pleistocene up to the Last Glacial Maximum (LGM); b) a general erosion event with valley incision in the upper fan, from the end of the LGM to the Early Holocene; and c) a new aggradational phase restricted to deposition in confined fluvial plains in the upper fan settings and in distributary lobes in intermediate to distal fan domains during the Holocene.

The ancient Cuiabá fan is marked by low-sinuous paleochannels arranged in a planform distributary network. OSL ages of the paleochannel sediments in the proximal and intermediate ancient

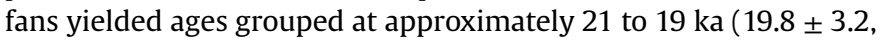
$20.6 \pm 2.1$ and $21.1 \pm 3.5 \mathrm{ka}$ ), but an older age of $49.2 \pm 6.0 \mathrm{ka}$ resulted from the dating of the sediments from a paleochannel at the distal part of the system. Theses ages indicate that the ancient fan was active until $19 \mathrm{ka}$, with the last important episode of sand accumulation during the LGM (23-19 ka), although the beginning of sedimentation might have started earlier into the Pleistocene. In addition, the similar burial ages of the sediments deposited by three paleochannels suggest a network of coeval distributary channels. This fan-shaped geometry was most likely a consequence of the convex up basin geometry and unconfined flows moving down dip, resembling the planform characteristics of the terminal fan model (Friend, 1978; Kelly and Olsen, 1993).

The relatively high topographic position of the paleochannels and their filling of sandy sediments are associated with well drained soils (Arenosols) and woodland vegetation, whereas grassland formations occur on adjacent inter-channel flood basins, where soils with clay rich B-horizons are well developed and shallow flooding occurs during the wet season (Zeilhofer and Schessl, 1999). The difference in soil development is also consistent with the stratigraphic superposition of paleochannels, indicating that distributary paleochannels are younger than the adjacent fan surface, and they represent the final sedimentation stage of the ancient fan. Narrow incised streams and unconfined sheet flows have reworked the sediments across the ancient fan after its abandonment. Thin sand sheets $(6.7 \pm 0.9 \mathrm{ka})$ are the depositional record of this reworking process. Today, the ancient Cuiabá fan represents a relict landform dominated by degradational processes.

A significant fluvial avulsion of the Cuiabá River near the apex marks the development of a new geomorphic phase. This avulsion caused a shifting of the main Cuiabá River channel to its present position and the abandonment of the ancient fan. Changes in the paleo-hydraulic conditions are interpreted to have triggered incision and valley widening due to lateral erosion by meandering rivers. The timing of the incision could not be precisely determined with our dataset because of the lack of a stratigraphic record that hinders a detailed chronological assessment. The cross-cutting relationships indicate that the valley was incised after the ancient fan deposition that ended at approximately $19.8 \pm 3.2 \mathrm{ka}$. The radiocarbon ages of 8540 and 8710 years BP (Beirigo, 2013; Zaparoli, 2015) from the sediments of the confined plains in the upper fan region probably indicate the initial phase of the meander belt infilling. Therefore, the available chronological data suggest that incision of the Cuiabá valley occurred during the last deglaciation, between the end of the LGM ( 19 ka) and the Early Holocene ( $9 \mathrm{ka}$ ).

Incised valleys are common features in fluvial fans of the Pantanal wetlands (Assine et al., 2015a). Nonetheless, the upper fan incision in the Cuiabá megafan differs from those observed in other Pantanal fluvial fans. The Cuiabá incised valley is placed on the edge of the system, while other fans have axial positions. Moreover, in the upper fan Cuiabá fluvial plains, there are contrasting channel patterns that are characterized by shifts from meandering to anabranching. Since the incision phase, a continuous meandering channel belt had become dominant in the confined fluvial plain. This is represented by the upper reaches of the Cuiabá River and its active meander belt as well as by the Piraim River, which represents the abandoned meander belt. However, a new avulsion shifted the river position and channel pattern. The mechanisms and chronology of the avulsion that abandoned the previous meander belt and built up the anabranching channel remain unknown. The current connection between the Cuiabá and Piraim Rivers indicates that the meander belt has not yet been completely abandoned, suggesting that the avulsion occurred during the Late Holocene or even in the last few centuries.

The confinement of the Cuiabá River in the upper fan setting was a key factor for the evolution of the unconfined fluvial plain because the feeder channel carried water and sediments through the confined plain to build-up the modern lobes. The Claro lobe resulted from this process and is noteworthy because its paleochannels display a similar morphology and dimension regarding the meandering Cuiabá/Piraim channels (Figs. 8 and 10). This suggests that the development of the Claro lobe resulted from lateral channel migration due to successive nodal avulsions in the proximal part of the lobe (Fig. 8).

Interestingly, the main direction of the channels in the Caracará lobe (ENE-WSW) suggests a previous connection between this drainage and the Piquiri River, a modern interfan system between the São Lourenço and the Taquari megafans (Fig. 9). This implies that the Piquiri River might have had a typical distributary channel pattern, instead of its current tributary pattern, and that the Cuiabá/ Paraguay confluence was approximately $100 \mathrm{~km}$ to the north. Thus, we interpret that both recent lobes have developed since the Early Holocene and the active lobe formed during the Late Holocene. OSL ages between $6.0 \pm 0.5 \mathrm{ka}$ and $1.7 \pm 0.2 \mathrm{ka}$ (Fonseca, 2015) obtained in a paleochannel within the Claro lobe also support this interpretation.

The depositional lobes are topographically elevated relative to the interlobe regions (Fig. 9), where erosion processes and sediment reworking dominate. In the interlobe regions, older paleochannel belts have been occupied by underfit streams with discharges at least one order of magnitude smaller than suggested by their planform. Sediment deficit and available accommodation space characterize the surrounding low-altitude areas, configuring suitable sites for future channel migration by avulsion and the 
development of new lobes.

An active avulsion point on the Cuiabá River occurs at the lowland between the Claro and Caracará lobes (Fig. 10B), where a secondary channel has led water and sediments out of the main channel and built a permanently swamped region with small lakes. This avulsion started in the early 1990s, but it is not possible to predict if it will force the complete abandonment of the Cuiabá River channel or if it is only a partial avulsion.

Avulsions are also frequent on the active lobe near the confluence with the Paraguay River (Fig. 10C) and resulted in a complex network of distributary channels as well as partially active and abandoned channels that cross a region with small lakes and swamps. The flooded region and the high channel mobility promote the increase of the sediment aggradation rates, often giving rise to small progradational lateral and terminal splays (Fig. 10D).

The modern Cuiabá fluvial fan can be classified as a singlesinuous fan type (Hartley et al., 2010), where the fan-shape has been produced by a perennial meandering river, with a low ratio between the sediment supply and water discharge. This condition favors a lateral channel shift due to successive nodal avulsions from the Cuiabá/Piraim River in the proximal part of the lobe. In a regional context, the closest analogue for the modern Cuiabá fan is the Paraguay fan, a fluvial fan that exhibits similar meandering channels due to low sediment yield sourced from dissected metamorphic terrains (Assine and Silva, 2009).

Weissmann et al. (2015) described meandering rivers in an incised valley producing chute and neck cutoff avulsions as well as the amalgamation of point bar deposits and originating an overprinted mix of scroll bar topography. By contrast, meandering rivers on unconfined plains commonly have less amalgamation processes and form alluvial ridges without evidence of overprinted scroll bars. This pattern, observed in the Taquari and São Lourenço fans (Assine, 2005; Assine et al., 2014), is somewhat different in the modern Cuiabá fluvial fan, where some meander belts display amalgamation, such as overprinted scroll bars, while others display single channels forming alluvial ridges with little evidence of amalgamation features (Fig. 10A). Weissmann et al. (2015) suggested that this type of meander belt implies that the channel remained at the same location long enough to produce an amalgamated channel belt, indicating relatively higher channel stability and a low frequency of avulsions. For the Cuiabá megafan, we interpret the relative stability of the channel to be a consequence of a low ratio between the sediment supply and water discharge once the river was sourced from low-relief terrains over metamorphic rocks with a low sediment yield.

\section{The role of tectonic and climate controls on fluvial fan evolution}

The inventory of depositional landforms in the Cuiabá megafan provides a characterization of geomorphic elements and evidence of changes in surface processes over time as well as their control of climate and/or tectonic factors in the northern Pantanal wetlands. The succession of depositional and erosional events imprinted on the Cuiabá megafan records environmental changes since at least $49.2 \pm 6.0 \mathrm{ka}$. Changes in channel patterns and phases of aggradation as well as incisions in distributary systems are widely reported to be responses to variations in the sediment supply and fluvial discharge, which are primarily driven by climate and secondarily by tectonic and base level changes (Bull, 1977; Weissmann et al., 2002, 2005; Nádor et al., 2003; Pope and Wilkinson, 2005; Gibling et al., 2005; Kumar et al., 2007; Fontana et al., 2008; Latrubesse et al., 2012).

Basin tectonics play an important role in the development of the Pantanal landscape (Soares et al., 1998; Assine and Soares, 2004;
Paranhos Filho et al., 2013). Shallow earthquakes commonly registered in the region (Dias et al., 2016) point to differential movements along fault surfaces, and the resulting subsidence of fault blocks controls the generation of accommodation space and the distribution of locations subject to periodic flooding (Assine et al., 2015a). The morphostructural characteristics of the Cuiabá megafan are consistent with a landscape evolving under tectonic control. Linear boundaries of flooded regions observed in satellite images suggest Quaternary fault trends, indicating that the NE-SW and NW-SE trending faults control the limits of the modern Cuiabá megafan (Fig. 11). The dominant NE-SW trending direction has been related to reactivation of basement structures (Paranhos Filho et al., 2013), which are mostly associated with the Transbrasiliano Fault System (Soares et al., 1998). In addition, the unconfined plain is within a long-lived subsiding area, as suggested by three drilled boreholes pointing to a sedimentary succession with at a thickness
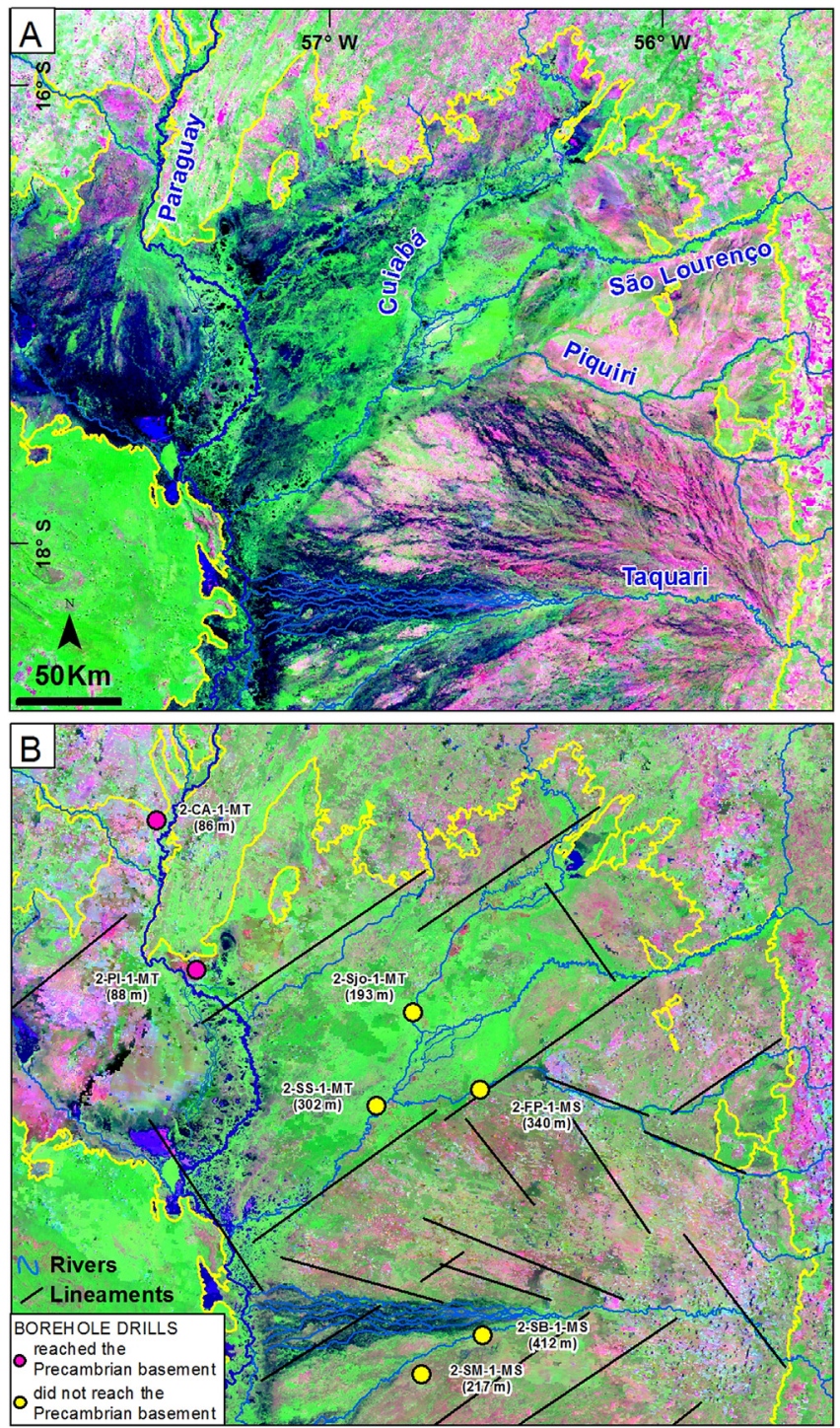

Fig. 11. Interpreted tectonic brittle structures (faults/fractures) that control the flooding and sedimentation sites in the Cuiabá megafan (after Assine et al., 2015a). Black and blue colors indicate distinct flooding patterns during wet (A) and dry (B) seasons. The yellow line is the wetland border (images MODIS/Terra MOD13Q1 R(MIR) G(EVI)B(Blue) composite band, wet season 2011 and dry season of 2008). (For interpretation of the references to colour in this figure legend, the reader is referred to the web version of this article.) 
of at least $\sim 340 \mathrm{~m}$ (Fig. 11). Therefore, this region is an active depositional site and subject to prolonged flooding events.

Local effects of tectonic structures on fluvial features are observed on the anabranching sector of the confined plain. Near Barão de Melgaço, the Cuiabá River deflects $90^{\circ}$ clockwise, and its southwest flow is controlled by the NE-SW basin border faults. Subsequently, the channel pattern changes to an anabranching channel that flows over a bed of iron-rich crusts without a thick layer of sediments, suggesting an erosive behavior of the channel. This sector of the floodplain has a lower elevation and is subject to strong annual floods, which appear to be related to a local subsiding region controlled by reactivation of the NE-SW basement structures.

Despite the long-term tectonic constraint, it appears unlikely that Late Pleistocene and Holocene tectonic activity triggered the shifts between the aggradation and degradation phases observed in the Cuiabá fluvial system. Considering the wide range of climate changes reported for the Late Quaternary of South America (e.g., Clapperton, 1993; Iriondo, 1999; Mayle et al., 2004; Cruz et al., 2009; Cheng et al., 2013; Baker and Fritz, 2015, and references therein), we suggest that climatically controlled changes in sediment and water fluxes can be considered to be the primary factors that drive periods of fan deposition and valley incision.

Abandoned lobes (ancient fan) at the upper portion of the Cuiabá megafan indicate that a phase of aggradation occurred during the last glacial period, at least between $48.4 \pm 5.8$ and $19.3 \pm 3.1 \mathrm{ka}$. The dating suggests deposition from Marine Isotope Stage (MIS) 3 (57-29 ka) to early MIS 2 (29-14 ka) (timescale from Lisiecki and Raymo, 2005), when paleochannels with similar morphologies were also recognized on the abandoned lobes of the Taquari (Assine and Soares, 2004; Zani et al., 2012) and São Lourenço (Assine et al., 2014) megafans in the eastern Pantanal. The results of other subtropical and tropical South America fluvial systems consider that a colder temperature, increase in rainfall seasonality and low vegetation cover would lead to torrential fluvial regimes, with high sediment production in catchment areas and widespread aggradation during the last glaciation, before the LGM (Iriondo, 1993, 1999; Iriondo and Latrubesse, 1994; Latrubesse, 2003; Stevaux, 2000; May et al., 2008; Latrubesse et al., 2012).

The network of distributary paleochannels preserved on the ancient fan surface is clear evidence of fluvial activity during the LGM ( 20 ka). The paleochannels morphology that becomes narrower and straighter downstream suggests discharge loss due to high percolation and evapotranspiration, implying a relatively low effective precipitation and reduced vegetation cover in the depositional site. This scenario of generally drier conditions would produce water flows with high variability over the year, leading to dry channels for most of the year, with flows occurring briefly during the summer months. Sedimentary features in other lowlands of South America have been interpreted as evidence of dryer and cooler conditions during the LGM than at present. An increase of aeolian activity with the development of loess and sand dune deposits in the Argentinean Pampa (Iriondo and García, 1993; Kröhling and Iriondo, 1999), southern Chaco (Iriondo, 1993) and Bolivian lowlands (May and Veit, 2009) have been associated with a regional drought during the LGM. Latrubesse et al. (2012) suggest that these drier conditions led to smaller discharges from the catchment and less fluvial activity in the Chaco plains. In addition, Latrubesse and Kalicki (2002) recognized a network of inactive fluvial belts in the middle Amazon, which were interpreted as two large fluvial fans deposited under arid conditions and intense avulsion processes at approximately $20 \mathrm{ka}$ (TL age).

Our data from the Late Pleistocene (48-19 ka) lobes of the Cuiabá megafan agree with environmental conditions interpreted from pollen records for regional lowlands. Stable carbon isotopes in bulk organic matter $\left(\delta^{13} \mathrm{C}\right)$, carbon and hydrogen stable isotopes in leaf wax $\left(\delta^{13} \mathrm{C}\right.$ and $\left.\delta \mathrm{D}\right)$ and pollen and diatom data from the Lagoa Gaiva sediments indicate an open vegetation landscape dominated by grasses and herbs during the last glacial period (41-20 ka) in the Pantanal wetland (Whitney et al., 2011; Metcalfe et al., 2014; Fornace et al., 2016). A similar scenario was interpreted through pollen and charcoal data from sediments of the Chaplin and Bella Vista Lakes in northeastern lowland Bolivia (southwestern Amazon Basin), which also suggest the expansion of dry forests and savannas during the last glacial period, especially during the LGM (Mayle et al., 2000; Burbridge et al., 2004). This trend of expansion of open vegetation regions has been primarily attributed to cooler temperatures $\left(\sim 5^{\circ} \mathrm{C}\right.$ below present) and reduced atmospheric $\mathrm{CO}_{2}$ concentrations in combination with a longer dry season during the last glacial period relative to the Holocene levels (e.g., Burbridge et al., 2004; Mayle et al., 2004).

Despite the great value of these records for environmental reconstruction, the interpretation of regional scenarios should be taken with parsimony. Burbridge et al. (2004) indicate that given that the Pleistocene pollen assemblages are dominated by pollen types that are poorly dispersed and/or produced in low quantities relative to wind-pollinated taxa, vegetation interpretations at the regional scale (i.e., beyond $2 \mathrm{~km}$ from the lake shore) are speculative. Other uncertainties may be related to the physiographic condition of the Pantanal sampling sites, considering that Lagoa Gaiva is a large and shallow lake that is strongly influenced by the Paraguay River (Assine and Silva, 2009; McGlue et al., 2011, 2012). Thus, some changes could be related to a large-scale reorganization of the drainage basin and river pathways and might not be directly related to changes in the regional vegetation pattern.

Moreover, the climate conditions reconstructed through vegetation changes interpreted for the last glacial period in South America is a highly controversial issue, considering the large number of pollen records from central and southeast Brazil (e.g., Salgado-Labouriau et al., 1997; Ledru et al., 2005) as well as stable carbon isotope data from soil samples taken along a $200 \mathrm{~km}$ transect across a savanna-rain forest mosaic between Porto Velho and Humaitá (de Freitas et al., 2001). These records suggest an expansion of humid forests during this period. Furthermore, oxygen isotope $\left(\delta^{18} \mathrm{O}\right)$ records of speleothems from southeast Brazil (Cruz et al., 2005, 2009) and the western Amazon lowlands (Cheng et al., 2013; Mosblech et al., 2012) indicate that rather wet conditions persisted for the SASM throughout most of the last glacial period, especially during the LGM.

Independent proxy data from several sites show that environmental changes were complex in tropical and subtropical South American lowlands from the Late Glacial Maximum to Early Holocene (Iriondo, 1999; Mayle et al., 2004; Cruz et al., 2009; Baker and Fritz, 2015). Iriondo (1999) argued that the early phase of deglaciation was accompanied by widespread torrential dynamics and fluvial erosion and that from approximately 16 to $15 \mathrm{ka}$, the climate became humid enough to mobilize carbonates (pedogenesis), but with sparse vegetation, permitting dune redistribution in the Argentinean Pampa. Glacial advance occurred from 14 to $8.5 \mathrm{ka}$, with a dry climate characterized by strong westerly winds in the Pampa (Iriondo, 1999).

Otherwise, the speleothems records $\left(\delta^{18} \mathrm{O}\right)$ indicate the occurrence of abrupt millennial precipitation events due to the strengthening of the SASM at the onset to the Heinrich stadial 1 (HS1) at $18.5 \mathrm{ka}$ and Younger Dryas (YD) at $~ 12.5 \mathrm{ka}$ (Cruz et al., 2005; Wang et al., 2007; Mosblech et al., 2012; Cheng et al., 2013; Zhang et al., 2016). Pollen records indicate that forest expansion in Pantanal (Whitney et al., 2011; Fornace et al., 2016) might have been coincident with forest expansion in the southwestern Amazonia (de Freitas et al., 2001; Burbridge et al., 2004) 
due to the increasing temperatures and global $\mathrm{CO}_{2}$ concentrations (Mayle et al., 2004).

Taking all this information into account, we suggest that global climate changes and consequent precipitation shifts induced in South American lowlands would be the primary driver of the changes in channel styles recorded by the Cuiabá River during the last glacial and deglacial periods. Higher precipitation combined with a denser vegetation cover may have increased the discharge and stream transport capacity during the HS1 and/or YD. Assuming that the youngest age of the ancient fan $(19.3 \pm 3.1 \mathrm{ka})$ is the maximum age for the beginning of the incision and that the radiocarbon ages of approximately $8.5 \mathrm{ka} \mathrm{BP}$ are related to the filling of the confined plains, we interpret that the upper fan valley incision in the Cuiabá megafan occurred in response to an abrupt increase in precipitation due to the strengthening of the SASM during the HS1 and YD.

A roughly similar timeframe of incision and infilling has been reported for other entrenched valleys in the Pantanal fluvial fans (Assine and Soares, 2004; Assine and Silva, 2009; Kuerten et al., 2013; Assine et al., 2014), suggesting a regional response of the Pantanal fluvial systems to abrupt climate changes during the LGM and subsequent deglaciation phase during the very late Pleistocene. After the incision phase, the main floods were confined in the incised valley and the channel pattern shifted from low-sinuous distributary to single-meander belts. This new channel pattern probably resulted from the establishment of denser vegetation cover in the catchment area and an overall reduction in sediment supply to the Cuiabá River. A similar pattern of channel incision was documented for the western Ganges River Plain (Gibling et al., 2005; Roy et al., 2012), in which an increase in precipitation due to the strengthening of the Southwest Indian Monsoon led to an increase in river discharge and promoted incision and widespread badland formation.

In contrast to the differences during the Late Pleistocene, the interpreted climatic changes through the Holocene are broadly consistent, even using distinct proxies. Speleothem paleoprecipitation records from southeast Brazil (Cruz et al., 2005, 2009) and the western Amazon lowlands (Cheng et al., 2013; Mosblech et al., 2012) show a large-scale decrease in $\delta^{18} \mathrm{O}$ values during the Early-Mid Holocene, suggesting relatively drier conditions due the weakening of the SASM. The lake levels in Pantanal during the Mid Holocene were lower than their modern levels, indicating a response to a relatively drier period, as shown by paleoprecipitation data (McGlue et al., 2012). This arid phase is correlated with an increase of fire events and the expansion of savanna vegetation in the southwest border of Amazonia (de Freitas et al., 2001; Mayle et al., 2004). The Cuiabá River valley infill likely accompanied a reduced stream capacity and stabilization of riverbanks by vegetation through the Early-Mid Holocene, under which fine-grained sediments and sand were deposited in fining-upward sequences by lateral meander shifting. Moreover, the Cuiabá River extended its meandering belts even to the distal parts of the modern fluvial fan due to the relatively high channel stability.

\section{Conclusion}

The approximately $15,300 \mathrm{~km}^{2}$ Cuiabá fluvial fan represents the second largest megafan within the Pantanal basin. The recognition of depositional and erosion features coupled with OSL dating enabled us to establish a succession of events that built up the Cuiabá megafan during the last $49 \mathrm{ka}$. The location and limits of the Cuiabá megafan result from the accommodation space produced by long-term tectonic processes, with the Late Pleistocene and Holocene precipitation changes playing a major role in aggradation and incision phases as well as shifts in the fluvial channel styles.
The ancient fan is marked by a distributary drainage network of low-sinuosity paleochannels, indicating that a phase of aggradation prevailed from MIS 3 (49 ka) to the LGM (19 ka). The fan-shaped geometry was a consequence of the convex up basin geometry and unconfined flows moving down dip. The morphology of the paleochannels grow narrower and straighter downstream, suggesting discharge loss due to high percolation and evapotranspiration. This scenario indicates relatively dry conditions, with low effective precipitation and a reduced vegetation cover at the LGM. Thus, the ancient fan is a relict landform under degradational processes.

The valley incision in the upper fan was driven by changes in hydrologic conditions in response to abrupt precipitation events due to the strengthening of the SASM during the HS1 and YD. The incision displays shifts between meandering and anabranching channel patterns over time. After the incision, increases in temperature and the atmospheric $\mathrm{CO}_{2}$ concentration favored the development of a denser vegetation cover and an increase of the channel bank stability, driving the channel pattern to meandering.

The modern Cuiabá fluvial fan comprises a perennial meandering river during the Holocene. It represents a singlesinuous fan style, with a relatively low sediment supply to water discharge ratio. Its fan-shape was built-up by the repeated construction and abandonment of the meander belts on an unconfined fluvial basin. The variations in the channel morphology reconstructed for the Cuiabá fluvial fan agree with previous works that reported low aggradation rates during the LGM as a result of drier conditions. The abrupt increase in precipitation after the LGM and development of denser vegetation cover during the deglacial period caused incised valleys and an overall shift to meandering or anabranching channels.

\section{Acknowledgments}

This research was funded by São Paulo Research Foundation (FAPESP) through grant \#2014/06889-2 and the set-up of the Luminescence and Gamma Spectrometry Laboratory (LEGaL) at University of São Paulo (grant \#2009/53988-8). FNP was supported by National Council for Scientific and Technological Development (CNPq grant 142721/2011-5) during the development of this research and currently has been supported by a FAPESP post-doc fellowship (grant \#2014/23334-4). MLA and AOS are supported by CNPq (grant \#308563/2013-1 and grant \#3009223/2014-8, respectively). We are grateful to Dr. Daniela Kröhling, Dr. Edgardo Latrubesse and an anonymous referee for their thoughtful comments. We are grateful to the Serviço Social do Comércio (Sesc) through the Estância Ecológica Sesc Pantanal, Dr. Aguinaldo Silva (UFMS), Hudson Macedo and Eder Merino (UNESP) for the logistics support during the fieldwork. We thank Luciana Nogueira and Thays Mineli for the technical support during OSL dating procedures.

\section{References}

Ab’Saber, A.N., 1988. O Pantanal Mato-Grossense e a teoria dos refúgios. Rev. Bras. Geogr. 50 (2), 9-57.

Adámoli, J., Pott, A., 1999. Las fuentes de biodiversidad en el Pantanal. In: Matteucci, S.D., Solbrig, O., Morello, J., Halffter, G. (Eds.), Biodiverdidad y uso de la tierra, conceptos y ejemplos de Latinoamérica. Eudeba/UNESCO, Buenos Aires, Argentina, pp. 317-361 (Cap. 15).

Alho, C.J.R., 2005. The World's Largest Wetlands: Ecology and Conservation.

Assine, M.L., 2005. River avulsions on the Taquari megafan, Pantanal wetland, Brazil. Geomorphology 70, 357-371.

Assine, M.L., Silva, A., 2009. Contrasting fluvial styles of the Paraguay River in the northwestern border of the Pantanal wetland, Brazil. Geomorphology 113, 189-199.

Assine, M.L., Soares, P.C., 2004. Quaternary of the Pantanal, west-central Brazil. Quat. Int. 114, 23-34. 
Assine, M.L., Corradini, F.A., Pupim, F.N., McGlue, M.M., 2014. Channel arrangements and depositional styles in the São Lourenço fluvial megafan, Brazilian Pantanal wetland. Sediment. Geol. 301, 172-184.

Assine, M.L., Merino, E.R., Pupim, F. do N., Macedo, H. de A., Santos, M.G.M. dos, 2015a. The Quaternary alluvial systems tract of the Pantanal Basin, Brazil. Braz. J. Geol. 45, 475-489.

Assine, M.L., Merino, E.R., Pupim, F.N., Warren, L.V., Guerreiro, R.L., McGlue, M.M., 2015b. Geology and geomorphology of the Pantanal basin. In: Bergier, Assine (Eds.), Dynamics of the Pantanal Wetland in South America. Springer, pp. 23-50.

Assine, M.L., Macedo, H.A., Stevaux, J.C., Bergier, I., Padovano, C.R., Silva, A., 2015c. Avulsive rivers in the hydrology of the Pantanal Wetland. In: Bergier, Assine (Eds.), Dynamics of the Pantanal Wetland in South America. Springer, pp. 51-82.

Assumpção, M., Ferreira, J., Barros, L., Bezerra, H., França, G.S., Barbosa, J.R., Menezes, E., Ribotta, L.C., Pirchiner, M., Do Nascimento, A., Dourado, J.C., 2014 Intraplate seismicity in Brazil. In: Talwani, Pradeep (Ed.), Intraplate Earthquakes. Cambridge University Press, pp. 50-71.

Baker, P.A., Fritz, S.C., 2015. Nature and causes of Quaternary climate variation of tropical South America. Quat. Sci. Rev. 124, 31-47.

Beirigo, R.M., 2013. Formação e degradação de feições redoximórficas em solos do Pantanal-MT. Universidade de São Paulo, Escola Superior de Agricultura "Luiz de Queiroz", Piracicaba.

Braun, E.H.G., 1977. Cone aluvial do Taquari, unidade geomórfica marcante na planície quaternária do Pantanal. Rev. Bras. Geogr. 39, 164-180.

Buehler, H.A., Weissmann, G.S., Scuderi, L.A., Hartley, A.J., 2011. Spatial and temporal evolution of an avulsion on the Taquari River distributive fluvial system from satellite image analysis. J. Sediment. Res. 81, 630-640.

Bull, W.B., 1977. The alluvial-fan environment. Prog. Phys. Geogr. 1, 222-270.

Burbridge, R., Mayle, F., Killeen, T., 2004. Fifty-thousand-year vegetation and climate history of Noel Kempff Mercado National Park, Bolivian Amazon. Quat. Res. 61, 215-230.

Chavez, A.Y., Kwarteng, P.S., 1989. Extracting spectral contrast in Landsat Thematic Mapper image data using selective principal component analysis. Photogramm. Eng. Remote Sens. 55, 339-348.

Cheng, H., Sinha, A., Cruz, F.W., Wang, X., Edwards, R.L., D'Horta, F.M., Ribas, C.C., Vuille, M., Stott, L.D., Auler, A.S., 2013. Climate change patterns in Amazonia and biodiversity. Nat. Commun. 4, 1411.

Clapperton, C., 1993. Quaternary Geology and Geomorphology of South America. Elsevier, Amsterdam.

Cruz, F.W., Burns, S.J., Karmann, I., Sharp, W.D., Vuille, M., Cardoso, A.O., Ferrari, J.A., Silva Dias, P.L., Viana, O., 2005. Insolation-driven changes in atmospheric circulation over the past 116,000 years in subtropical Brazil. Nature 434, 63-66.

Cruz, F.W., Vuille, M., Burns, S.J., Wang, X., Cheng, H., Werner, M., Lawrence Edwards, R., Karmann, I., Auler, A.S., Nguyen, H., 2009. Orbitally driven east-west antiphasing of South American precipitation. Nat. Geosci. 2, 210-214.

DeCelles, P.G., Cavazza, W., 1999. A comparison of fluvial megafans in the Cordilleran (Upper Cretaceous) and modern Himalayan foreland basin systems. Bull. Geol. Soc. Am. 111, 1315-1334.

Dias, F.L., Assumpção, M., Facincani, E.M., Franca, G.S., Assine, M.L., Paranhos Filho, A.C., Gamarra, R.M., 2016. The 2009 earthquake, magnitude mb 4.8, in the Pantanal Wetlands, west-central Brazil. An. Acad. Bras. Cienc. 88 (3), 1253-1264.

Fantin-Cruz, I., Pedrollo, O., Castro, N.M.R., Girard, P., Zeilhofer, P., Hamilton, S.K., 2011. Historical reconstruction of floodplain inundation in the Pantanal (Brazil) using neural networks. J. Hydrol. 399, 376-384.

Paranhos Filho, A.C., Nummer, A.R., Albrez, E.A., Ribeiro, A.A., Machado, R., 2013. A study of structural lineaments in Pantanal (Brazil) using remote sensing data، An. Acad. Bras. Cienc. 85, 913-922.

Fonseca, G.P.D.S., 2015. Formas de relevo e os materiais de superfície no pantanal de Poconé-MT. Universidade de São Paulo, Faculdade de Filosofia, Letras e Ciências Humanas, São Paulo.

Fontana, A., Mozzi, P., Bondesan, A., 2008. Alluvial megafans in the VenetianFriulian plain (north-eastern Italy): evidence of sedimentary and erosive phases during Late Pleistocene and Holocene. Quat. Int. 189, 71-90.

Fornace, K.L., Whitney, B.S., Galy, V., Hughen, K.A., Mayle, F.E., 2016. Late Quaternary environmental change in the interior South American tropics: new insight from leaf wax stable isotopes. Earth Planet. Sci. Lett. 438, 75-85.

Fraser, L.H., Keddy, P.A., 2005. The World's Largest Wetlands: Ecology and Conservation. Cambridge University Press.

de Freitas, H.A., Pessenda, L.C.R., Aravena, R., Gouveia, S.E.M., de Souza Ribeiro, A., Boulet, R., 2001. Late Quaternary vegetation dynamics in the southern Amazon Basin inferred from carbon isotopes in soil organic matter. Quat. Res. 55 (1), 39-46.

Friend, P.F., 1978. Distinctive features of some ancient river systems. In: Miall, A.D. (Ed.), Fluvial Sedimentology: Canadian Society of Petroleum Geologists Memoir, vol. 5, pp. 531-542.

Galbraith, R.F., Roberts, R.G., Laslett, G.M., Yoshida, H., Olley, J.M., 1999. Optical dating of single and multiple grains of quartz from Jinmium rock shelter, northern Australia: Part I, experimental design and statistical models. Archaeometry 41, 339-364.

Garreaud, R.D., Vuille, M., Compagnucci, R., Marengo, J., 2009. Present-day South American climate. Palaeogeogr. Palaeoclimatol. Palaeoecol. 281 (3), 180-195.

Gibling, M.R., Tandon, S.K., Sinha, R., Jain, M., 2005. Discontinuity-bounded alluvial sequences of the southern Gangetic Plains, India: aggradation and degradation in response to monsoonal strength. J. Sediment. Res. 75, 369-385.

Guérin, G., Mercier, N., Adamiec, G., 2011. Dose-rate conversion factors: update. Anc. TL 29, 5-8.

Hamilton, S.K., 2002. Hydrological controls of ecological structure and function in the Pantanal wetland (Brazil). In: McClain, M.E. (Ed.), The Ecohydrology of South American Rivers and Wetlands. IAHS Press, Centre for Ecology and Hydrology, Oxfordshire UK, pp. 133-158.

Hartley, A.J., Weissmann, G.S., Nichols, G.J., Warwick, G.L., 2010. Large distributive fluvial systems: characteristics, distribution, and controls on development. J. Sediment. Res. 80, 167-183.

Horton, B.K., DeCelles, P.G., 1997. The modern foreland basin system adjacent to the Central Andes. Geology 25 (10), 895-898.

Horton, B.K., Decelles, P.G., 2001. Modern and ancient fluvial megafans in the foreland basin system of the central Andes, southern Bolivia: implications for drainage network evolution in fold- thrust belts. Basin Res. 13, 43-63.

Iriondo, M., 1993. Geomorphology and Late Quaternary of the Chaco (South America). Geomorphology 7 (4), 289-303.

Iriondo, M., 1999. Climatic changes in the South American plains: records of a continent-scale oscillation. Quat. Int. 57, 93-112.

Iriondo, M.H., García, N.O., 1993. Climatic variations in the Argentine plains during the last 18,000 years. Palaeogeogr. Palaeoclimatol. Palaeoecol. 101 (3-4), 209-220.

Iriondo, M., Latrubesse, E.M., 1994. A probable scenario for a dry climate in central Amazonia during the late Quaternary. Quat. Int. 21, 121-128.

Junk, W.J., Da Cunha, C.N., Wantzen, K.M., Petermann, P., Strüssmann, C. Marques, M.I., Adis, J., 2006. Biodiversity and its conservation in the Pantanal of Mato Grosso, Brazil. Aquat. Sci. 68 (3), 278-309.

Kelly, S.B., Olsen, H., 1993. Terminal fans - a review with reference to Devonian examples. Sediment. Geol. 85, 339-374.

Klammer, G., 1982. Die Palaeowuste des Pantanal von Mato Grosso und die pleistozane Klimageschichte des brasilianischen Randtropen. Z. Geomorphol. 26 (4), 393-416.

Kröhling, D.M., Iriondo, M., 1999. Upper Quaternary palaeoclimates of the Mar Chiquita area, North Pampa, Argentina. Quat. Int. 57, 149-163.

Kuerten, S., Parolin, M., Assine, M.L., McGlue, M.M., 2013. Sponge spicules indicate Holocene environmental changes on the Nabileque River floodplain, southern Pantanal, Brazil. J. Paleolimnol. 49, 171-183.

Kumar, R., Suresh, N., Sangode, S.J., Kumaravel, V., 2007. Evolution of the Quaternary alluvial fan system in the Himalayan foreland basin: implications for tectonic and climatic decoupling. Quat. Int. 159, 6-20.

LaLonde, T., Shortridge, A., Messina, J., 2010. The influence of land cover on shuttle radar topography mission (SRTM) elevations in low-relief areas. Trans. GIS 14 $461-479$.

Latrubesse, E.M., 2003. The Late-quaternary Palaeohydrology of Large South American Fluvial Systems Palaeohydrology: Understanding Global Change, 193pp.

Latrubesse, E.M., 2015. Large rivers, megafans and other Quaternary avulsive fluvia systems: a potential "who's who" in the geological record. Earth-Sci. Rev. 146 $1-30$.

Latrubesse, E.M., Kalicki, T., 2002. Late quaternary palaeohydrological changes in the Upper Purus basin, southwestern Amazonia, Brazil. Z. Geomorphol. 129, 41-59.

Latrubesse, E.M., Stevaux, J.C., Cremon, E.H., May, J.H., Tatumi, S.H., Hurtado, M.A. Bezada, M., Argollo, J.B., 2012. Late Quaternary megafans, fans and fluvioaeolian interactions in the Bolivian Chaco, Tropical South America. Palaeogeogr. Palaeoclimatol. Palaeoecol. 356-357, 75-88.

Ledru, M.P., Rousseau, D.D., Cruz, F.W., Riccomini, C., Karmann, I., Martin, L., 2005 Paleoclimate changes during the last $100,000 \mathrm{yr}$ from a record in the Brazilian Atlantic rainforest region and interhemispheric comparison. Quat. Res. 64, 444-450.

Leier, A.L., DeCelles, P.G., Pelletier, J.D., 2005. Mountains, monsoons, and megafans. Geology 33, 289-292.

Lisiecki, L.E., Raymo, M.E., 2005. A Pliocene-Pleistocene stack of 57 globally distributed benthic $\delta^{18} \mathrm{O}$ records. Paleoceanography 20 (1).

Makaske, B., Maathuis, B.H.P., Padovani, C.R., Stolker, C., Mosselman, E Jongman, R.H.G., 2012. Upstream and downstream controls of recent avulsions on the Taquari megafan, Pantanal, south-western Brazil. Earth Surf. Process. Landforms 37, 1313-1326.

May, J.H., Veit, H., 2009. Late Quaternary paleosols and their paleoenvironmenta significance along the Andean piedmont, Eastern Bolivia. Catena 78 (2), $100-116$.

May, J.H., Zech, R., Veit, H., 2008. Late Quaternary paleosol-sediment-sequences and landscape evolution along the Andean piedmont, Bolivian Chaco. Geomorphology 98, 34-54.

Mayle, F.E., Burbridge, R., Killeen, T.J., 2000. Millennial-scale dynamics of southern Amazonian rain forests. Science 290, 2291-2294.

Mayle, F.E., Beerling, D.J., Gosling, W.D., Bush, M.B., 2004. Responses of Amazonian ecosystems to climatic and atmospheric carbon dioxide changes since the last glacial maximum. Philos. T. Roy. Soc. B 359 (1443), 499-514.

McGlue, M.M., Silva, A., Corradini, F.A., Zani, H., Trees, M.A., Ellis, G.S., Parolin, M. Swarzenski, P.W., Cohen, A.S., Assine, M.L., 2011. Limnogeology in Brazil's "forgotten wilderness": a synthesis from the large floodplain lakes of the Pantanal. J. Paleolimnol. 46, 273-289.

McGlue, M.M., Silva, A., Zani, H., Corradini, F.A., Parolin, M., Abel, E.J., Cohen, A.S., Assine, M.L., Ellis, G.S., Trees, M.A., Kuerten, S., Gradella, F., dos, S., Rasbold, G.G., 
2012. Lacustrine records of Holocene flood pulse dynamics in the Upper Paraguay River watershed (Pantanal wetlands, Brazil). Quat. Res. 78, 285-294.

Merino, E.R., Assine, M.L., Pupim, F.N., 2013. Estilos Fluviais e Evidências de Mudanças Ambientais na Planície do Rio Miranda. Pantanal. Rev. Bras. Geomorfol. 14, 127-134.

Metcalfe, S.E., Whitney, B.S., Fitzpatrick, K.A., Mayle, F.E., Loader, N.J., StreetPerrott, F.A., Mann, D.G., 2014. Hydrology and climatology at Laguna La Gaiba, lowland Bolivia: complex responses to climatic forcings over the last 25000 years. J. Quat. Sci. 29, 289-300.

Mosblech, N.A.S., Bush, M.B., Gosling, W.D., Hodell, D., Thomas, L., van Calsteren, P. Correa-Metrio, A., Valencia, B.G., Curtis, J., van Woesik, R., 2012. North Atlantic forcing of Amazonian precipitation during the last ice age. Nat. Geosci. 5, $817-820$.

Murray, A.S., Wintle, A.G., 2000. Luminescence dating of quartz using an improved single- aliquot regenerative-dose protocol. Radiat. Meas. 32 (1), 57-73.

Murray, A.S., Wintle, A.G., 2003. The single aliquot regenerative dose protocol: potential for improvements in reliability. Radiat. Meas. 37 (4-5), 377-381.

Nádor, A., Lantos, M., Tóth-Makk, Á., Thamó-Bozsó, E., 2003. Milankovitch-scale multi-proxy records from fluvial sediments of the last 2.6 Ma, Pannonian Basin. Hung. Quat. Sci. Rev. 22, 2157-2175.

Nanson, G.C., Knighton, A.D., 1996. Anabranching rivers: their cause, character and classification. Earth Surf. Process Landforms 21, 217-239.

Pope, R.J.J., Wilkinson, K.N., 2005. Reconciling the roles of climate and tectonics in Late Quaternary fan development on the Spartan piedmont, Greece. Geol. Soc. Lond. Spec. Publ. 251, 133-152.

Por, F.D., 1995. The Pantanal of Mato Grosso (Brazil). Kluwer, Dordrecht.

Prance, G.T., Schaller, G., 1982. Preliminary study of some vegetation types of the Pantanal, Mato Grosso, Brazil. Brittonia 34, 228-251.

Prescott, J.R., Hutton, J.T., 1994. Cosmic ray contributions to dose rates for luminescence and ESR dating: large depths and long-term time variations. Radiat. Meas. 23, 497-500.

Pupim, F.N., Bierman, P.R., Assine, M.L., Rood, D.H., Silva, A., Merino, E.R., 2015 Erosion rates and landscape evolution of the lowlands of the Upper Paraguay River basin (Brazil) from cosmogenic ${ }^{10} \mathrm{Be}$. Geomorphology 234, 151-160.

Rodríguez, E., Morris, C.S., Belz, J.E., 2006. A global assessment of the SRTM performance. Photogramm. Eng. Remote Sens. 72, 249-260.

Rossetti, D.F., Zani, H., Cremon, É.H., 2014. Fossil megafans evidenced by remote sensing in the Amazonian wetlands. Z. Geomorphol. 58 (2), 145-161.

Roy, N.G., Sinha, R., Gibling, M.R., 2012. Aggradation, incision and interfluve flooding in the Ganga Valley over the past 100,000years: testing the influence of monsoonal precipitation. Palaeogeogr. Palaeoclimatol. Palaeoecol. 356-357, $38-53$.

Salgado-Labouriau, M.L., Casseti, V., Ferraz-Vicentini, K.R., Martin, L., Soubiès, F., Suguio, K., Turcq, B., 1997. Late Quaternary vegetational and climatic changes in cerrado and palm swamp from Central Brazil. Palaeogeogr. Palaeoclimatol. Palaeoecol. 128 (1), 215-226.

Sinha, R., Friend, P.F., 1994. River systems and their sediment flux, Indo-Gangetic plains, Northern Bihar, India. Sedimentology 41, 825-845.

Soares, P.C., Assine, M.L., Rabelo, L., 1998. The Pantanal Basin: recent tectonics, relationships to the Transbrasiliano Lineament. An. IX Simpósio Bras.
Sensoriamento Remoto 459-469.

Stevaux, J.C., 2000. Climatic events during the late Pleistocene and Holocene in the upper Parana River: correlation with NE Argentina and South-Central Brazil. Quat. Int. 72, 73-85.

Tricart, J., 1982. El Pantanal: un ejemplo del impacto geomorfologico sobre el ambiente. Investig. Geográficas 29, 81-97.

Ussami, N., Shiraiwa, S., Dominguez, J.M.L., 1999. Basement reactivation in a subAndean foreland flexural bulge: the Pantanal Wetland, SW Brazil. Tectonics 18 (1), 25-39.

Valeriano, M.M., Kuplich, T.M., Storino, M., Amaral, B.D., Mendes, J.N., Lima, D.J., 2006. Modeling small watersheds in Brazilian Amazonia with shuttle radar topographic mission-90m data. Comput. Geosci. 32, 1169-1181.

Wang, X., Auler, A.S., Edwards, R.L., Cheng, H., Ito, E., Wang, Y., Kong, X., Solheid, M., 2007. Millennial-scale precipitation changes in southern Brazil over the past 90,000 years. Geophys. Res. Lett. 34 (23), L23701.

Weissmann, G.S., Mount, J.F., Fogg, G.E., 2002. Glacially driven cycles in accumulation space and sequence stratigraphy of a stream-dominated alluvial fan, San Joaquin Valley, California, U.S.A. J. Sediment. Res. 72, 240-251.

Weissmann, G.S., Bennett, G.L., Lansdale, A.L., 2005. Factors controlling sequence development on Quaternary fluvial fans, San Joaquin Basin, California, USA. Spec. Publ. Soc. Lond. 251, 169.

Weissmann, G.S., Hartley, A.J., Nichols, G.J., Scuderi, L.A., Olson, M., Buehler, H., Banteah, R., 2010. Fluvial form in modern continental sedimentary basins: distributive fluvial systems. Geology 38, 39-42.

Weissmann, G.S., Hartley, A.J., Scuderi, L.A., Nichols, G.J., Owen, A., Wright, S., Felicia, A.L., Holland, F., Anaya, F.M.L., 2015. Fluvial geomorphic elements in modern sedimentary basins and their potential preservation in the rock record: a review. Geomorphology 250, 187-219.

Whitney, B.S., Mayle, F.E., Punyasena, S.W., Fitzpatrick, K.A., Burn, M.J., Guillen, R., Chavez, E. Mann, D., Pennington, R.T. Metcalfe, S.E., 2011. A 45kyr palaeoclimate record from the lowland interior of tropical South America. Palaeogeogr. Palaeoclimatol. Palaeoecol. 307, 177-192.

Wilkinson, M.J., Marshall, L.G., Lundberg, J.G., 2006. River behavior on megafans and potential influences on diversification and distribution of aquatic organisms. J. South Am. Earth Sci. 21, 151-172.

Zani, H., Assine, M.L., McGlue, M.M., 2012. Remote sensing analysis of depositional landforms in alluvial settings: Method development and application to the Taquari megafan, Pantanal (Brazil). Geomorphology 161-162, 82-92.

Zaparoli, F.C.M., 2015. Evolução geomorfológica da Planície do Rio Cuiabá, Pantanal Mato-Grossense. Universidade Estadual Paulista, Instituto de Geociências e Ciências Exatas, Rio Claro.

Zeilhofer, P., Schessl, M., 1999. Relationship between vegetation and environmental conditions in the Northern Pantanal of Mato Grosso, Brazil. J. Biogeogr. 27, 159-168.

Zhang, Y., Zhang, X., Chiessi, C.M., Mulitza, S., Zhang, X., Lohmann, G., Prage, M., Behling, H., Zabel, M., Govin, A., Sawakuchi, A.O., Cruz, F.W., Wefer, G., 2016. Equatorial Pacific forcing of western Amazonian precipitation during Heinrich Stadial 1. Sci. Rep. 6, 35866.

Zhou, J., Lau, K.M., 1998. Does a monsoon climate exist over South America? J. Clim. 11 (5), 1020-1040. 